\title{
Petrology and Sedimentology of the Horlick Formation (Lower Devonian), \\ Ohio Range, Transantarctic Mountains
}

\section{GEORGIA TECH \\ LIBPARY}

NOV 181987

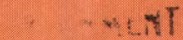

WuritithS

UtivailoRY

\section{U.S. GEOLOGICAL SURVEY BULLETIN 1780}

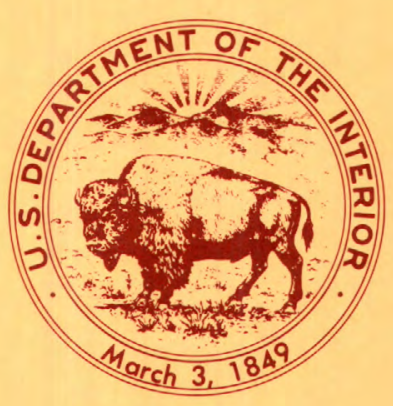





\section{Petrology and Sedimentology of the Horlick Formation (Lower Devonian), Ohio Range, Transantarctic Mountains}

\section{By LUCY MCCARTAN and MARGARET A. BRADSHAW}

The Horlick Formation is a nearshore marine deposit of fossiliferous sandstone and shale; it is the oldest sedimentary formation in the Ohio Range
GEORGIA TECH

LIBRARY

NOV 181987

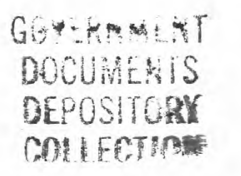




\title{
DEPARTMENT OF THE INTERIOR \\ DONALD PAUL HODEL, Secretary
}

\author{
U.S. GEOLOGICAL SURVEY \\ Dallas L. Peck, Director
}

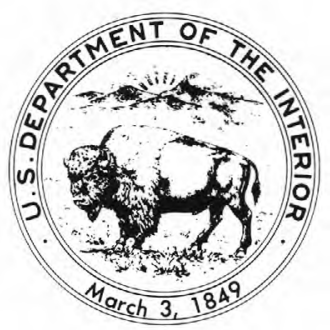

UNITED STATES GOVERNMENT PRINTING OFFICE: 1987

For sale by the Books and Open-File Reports Section, U.S. Geological Survey, Federal Center, Box 25425, Denver, CO 80225

\section{Library of Congress Cataloging in Publication Data}

McCartan, Lucy.

Petrology and sedimentology of the Horlick Formation

(Lower Devonian), Ohio Range, Transantarctic Mountains.

(U.S. Geological Survey bulletin ; 1780)

Bibliography: $p$.

Supt. of Docs. no. : I 19.3:1780

1. Sandstone-Antarctic regions-Transantarctic Mountains.

2. Shale-Antarctic regions-Transantarctic Mountains. 3.

Sedimentation and deposition-Antarctic regions-

Transantarctic Mountains. 4. Geology, Stratigraphic-

Devonian. 5. Geology-Antarctic regions-Transantarctic

Mountains. I. Bradshaw, Margaret A. II. Title. III. Series.

QE75.B9 no. 1780 557.3 s 87-600005

[QE471.15.S25] [551.7'4'09989] 


\section{CONTENTS}

Abstract 1

Introduction 1

Acknowledgments 1

Description of the Horlick Formation 7

Stratigraphic and structural setting 7

Detailed lithostratigraphy determined from measured sections 7

Section 1, Discovery Ridge 10

Sections 2 and 3, Discovery Ridge 18

Sections 4-6, central Ohio Range 18

Sections 7, 8, 9A, 9B, 10A, and 10B, Darling Ridge 19

Sections 11-15, Lackey Ridge 21

Petrology and mineralogy 23

Depositional environments of the Horlick Formation 24

Current-direction indicators $\mathbf{2 4}$

Direction of water movement 24

Distribution of textures and sedimentary structures 29

Tectonism and paleogeography $\mathbf{3 0}$

Conclusions $\mathbf{3 0}$

References cited $\mathbf{3 0}$

\section{FIGURES}

1. Topographic map of part of the Ohio Range, Transantarctic Mountains, showing locations of outcrops and of measured sections 1-15 2

2. Map of part of the Ohio Range showing geology of the outcrops 4

3. Photograph and sketch showing the predominantly north-facing escarpment along the Ohio Range 6

4. Summary diagram showing textures of measured sections 1-15 through the Horlick Formation, Ohio Range 11

5. Measured section 1, Discovery Ridge 12

6. Measured sections $1-3$, Discovery Ridge 13

7. Photographs of a hand specimen and a thin section of lithofacies $1 \quad 14$

8. Photograph of the base of the Horlick Formation at Lackey Ridge $\mathbf{1 4}$

9. Photographs of a hand specimen and a thin section of lithofacies $2 \mathbf{1 5}$

10. Photographs of a hand specimen and a thin section of lithofacies $3 \quad \mathbf{1 5}$

11. Photographs of two hand specimens and three thin sections of lithofacies 4 and of the contact between lithofacies 3 and $4 \quad 16$

12. Photographs of a hand specimen and a thin section of lithofacies $7 \quad \mathbf{1 7}$

13. Photographs of a hand specimen and a thin section of lithofacies $8 \mathbf{1 8}$ 
14. Photograph of the top of the Horlick Formation at Discovery Ridge 18

15. Measured sections 4-6, central Ohio Range 19

16. Measured sections 7, 8, 9A, 9B, 10A, and 10B, Darling Ridge 20

17. Measured sections $11-15$, Lackey Ridge 22

18. Photographs of a hand specimen and a thin section of the granite underlying the Horlick Formation at Discovery Ridge 23

19-21. Diagrams showing data on current-direction indicators in measured sections through marine deposits of the Horlick Formation-map-view orientation of indicatois:

19. Shown by arrows and lines at the correct level beside texture diagrams of the measured sections $\mathbf{2 5}$

20. Described in linear notation at the correct level for each measured section 26

21. Summarized for each $10-\mathrm{m}$ interval within the measured sections 27

22. Block diagram and map showing shoreline position and directions of water movement during deposition of the Horlick Formation

\section{TABLES}

1. Lithofacies 1-9 of the Horlick Formation 8

2. Mineralogy of Horlick Formation sandstone and source rock 9 


\section{Petrology and Sedimentology of the Horlick Formation (Lower Devonian), Ohio Range, Transantarctic Mountains}

\section{By Lucy McCartan ${ }^{1}$ and Margaret A. Bradshaw ${ }^{2}$}

\begin{abstract}
The Horlick Formation of Early Devonian age is as thick as $50 \mathrm{~m}$ and consists of subhorizontal, interbedded subarkosic sandstone and chloritic shale and mudstone. The Horlick overlies an erosion surface cut into Ordovician granitic rocks and is, in turn, overlain by Carboniferous and Permian glacial and periglacial deposits. Textures, sedimentary structures, and ubiquitous marine body fossils and animal traces suggest that the Horlick was deposited on a shallow shelf having moderate wave energy and a moderate tidal range. The source terrane probably lay to the north, and longshore transport was toward the west.
\end{abstract}

\section{INTRODUCTION}

The purpose of this paper is to present new petrologic and sedimentologic data from our study of the Horlick Formation in the Ohio Range at the edge of the East Antarctic craton. The Horlick is important because it contains the earliest known Devonian marine strata in Antarctica.

The Ohio Range is in the Transantarctic Mountains, Antarctica, at about lat $85^{\circ} \mathrm{S}$. between long $111^{\circ}$ and $117^{\circ}$ W. (fig. 1). The Horlick Formation contains abundant fossils of Early Devonian age and is the oldest sedimentary unit in the Ohio Range. The subhorizontal strata of the Horlick unconformably overlie granitic rocks of Ordovician age and are, in turn, overlain by as much as $900 \mathrm{~m}$ of sedimentary deposits of Carboniferous, Permian, and possibly even younger age (figs. 2,3 ); locally, the sedimentary units overlying the Horlick are capped by diabase that is probably Jurassic.

Previous workers in the Ohio Range concentrated chiefly on the rocks above the Horlick Formation (Long, 1965; Frakes and others, 1966). In the only previous major report on the Ohio Range, Long (1965) presented a geologic map that was used in planning the present study. Boucot and others $(1963,1969)$ and Doumani and others

\footnotetext{
${ }^{1}$ U.S. Geological Survey, Reston, Virginia.

${ }^{2}$ Canterbury Museum, Christchurch, New Zealand.
}

(1965) established the age of the Horlick Formation as Early Devonian (Emsian) on the basis of the brachiopods Australospirifer, Pleurothyrella, and Tanerhynchia, and the worm tube Tentaculites. Treves (1965) gave K-Ar (biotite) and $\mathrm{Rb}-\mathrm{Sr}$ (feldspar) ages of the underlying granite as about $470 \mathrm{Ma}$, Middle Ordovician.

In the brief austral summer of 1979-80, we collected specimens, measured sections, and traced beds laterally in order to establish three-dimensional relationships among the lithofacies of the Horlick Formation. Subsequent work included identification of the fossils (by Bradshaw) and petrologic analyses (mainly by McCartan). Paleoecologic and sedimentologic interpretations were made jointly. Our most important discoveries are the almost wholly marine nature of the Horlick and the strongly dominant westward longshore sediment transfer.

Overviews of the major findings of this study were presented in an earlier paper (Bradshaw and McCartan, 1983) that emphasized paleoecology and in a geologic map (McCartan, Bradshaw, and Kellogg, 1986). In this paper, we emphasize petrology and sedimentary structures and present a detailed reconstruction of the Early Devonian coastal plain that will be useful in global paleogeographic studies. Our findings will also be valuable for comparison with time-correlative units in New Zealand and elsewhere.

The report is divided into three parts: introduction and geologic setting; description of lithostratigraphy, petrology, and sedimentary structures; and discussion and interpretation of the data.

\section{Acknowledgments}

The help of Karl Kellogg (U.S. Geological Survey, USGS) and Graeme Ayres (New Zealand National Park Service) in the Ohio Range was essential to the success of the expedition. Kellogg and Ahmed El Basli (USGS) provided and analyzed a thin section and slab of the granite; Kellogg and Juergen Reinhardt (USGS) reviewed the manuscript. We are also grateful for the invitation of the New Zealand government for McCartan and Kellogg 


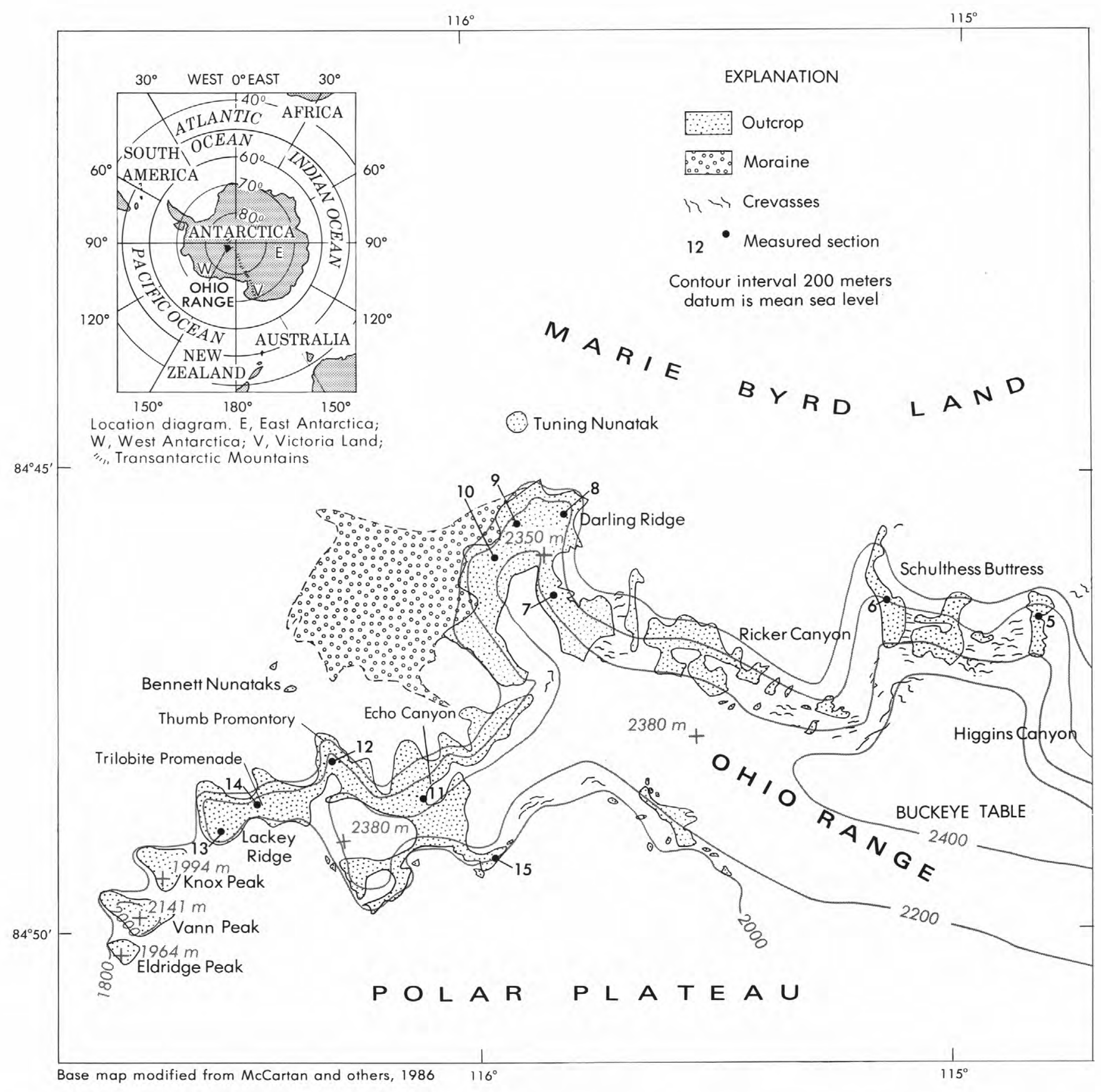

Figure 1. Topographic map of part of the Ohio Range, Transantarctic Mountains, showing locations of outcrops and of measured sections 1-15. Contours and outcrop outlines are approximate and are based on U.S. Geological
Survey (1963), McCartan and others (1986), and Long (1965). Solid-rock outcrops and moraines are surrounded by snow and ice. Geology of outcrops west of long $114^{\circ}$ $W$. is shown in figure 2 . 


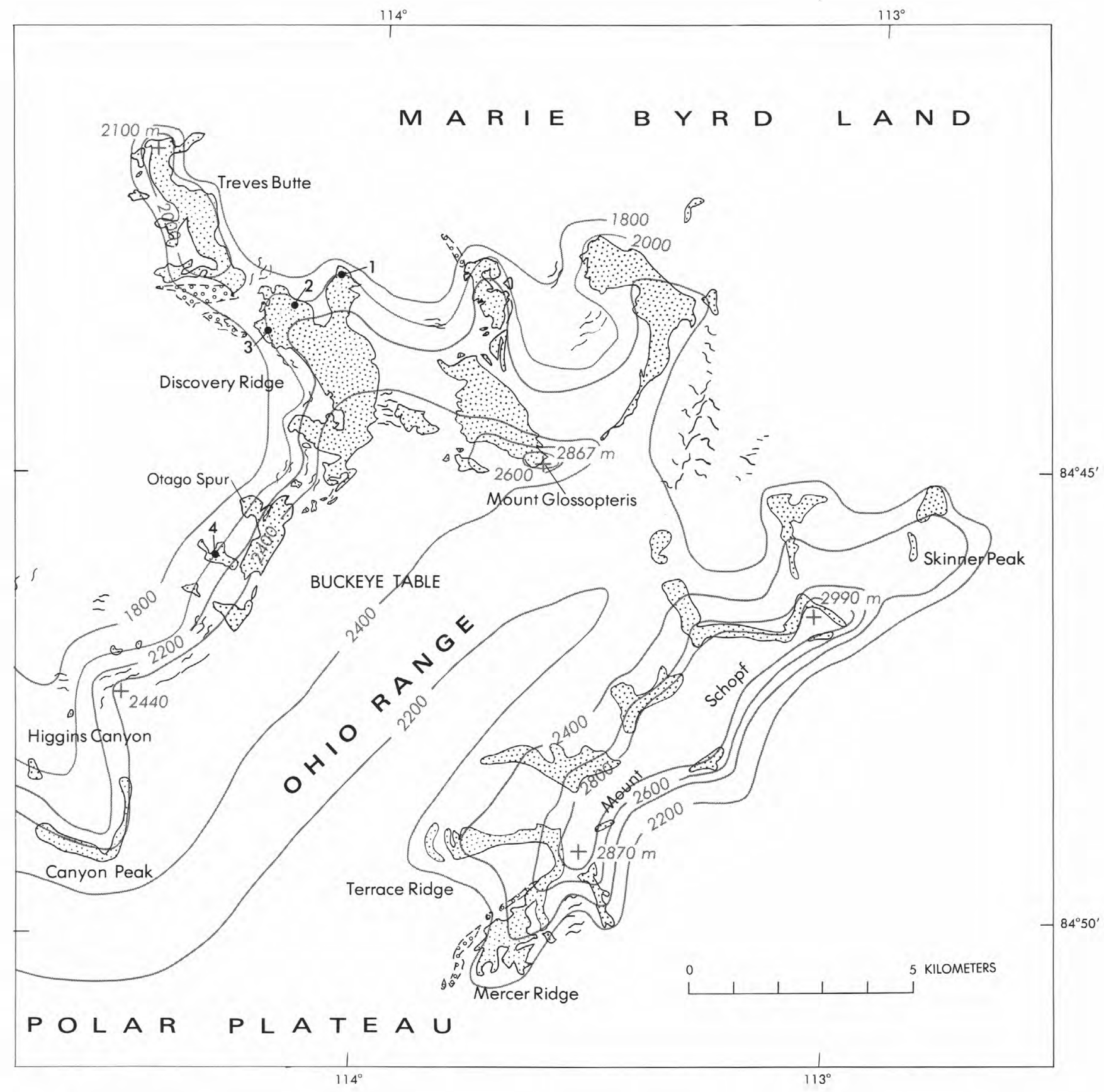

Figure 1. Continued. 


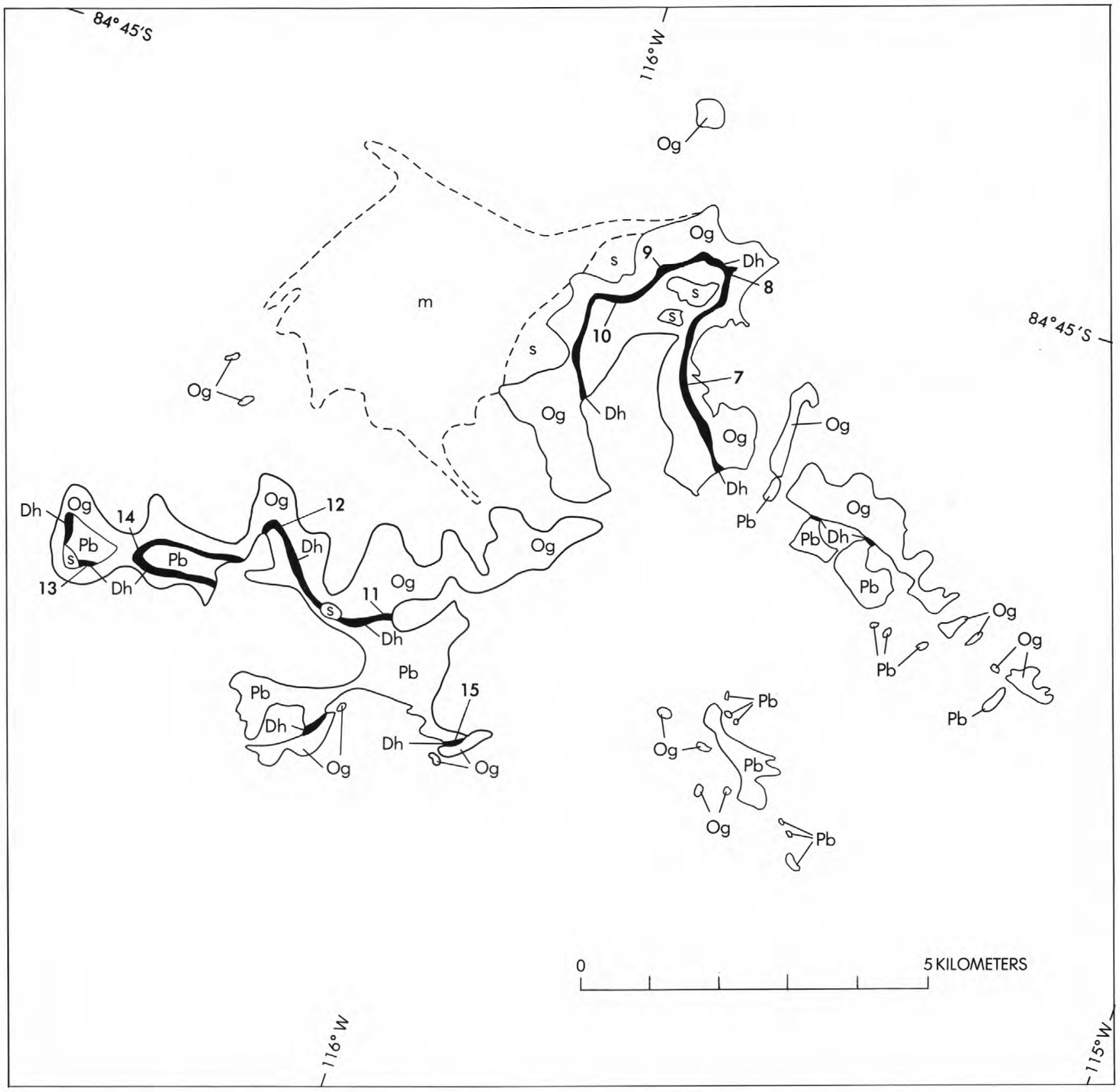

Figure 2. Map of part of the Ohio Range showing geology of the outcrops. Post-Devonian geology modified from Long (1965). Symbols used: s, Quaternary snow and ice; $\mathrm{m}$, Quaternary moraine; Pm, Mount Glossopteris Formation

Buckeye Tillite (Permian and Carboniferous); Dh, Horlick Formation (Lower Devonian); Og, Ordovician granite. Outcrops are surrounded by snow and ice. Locations of measured sections 1-15 are shown here and in figure 1. 


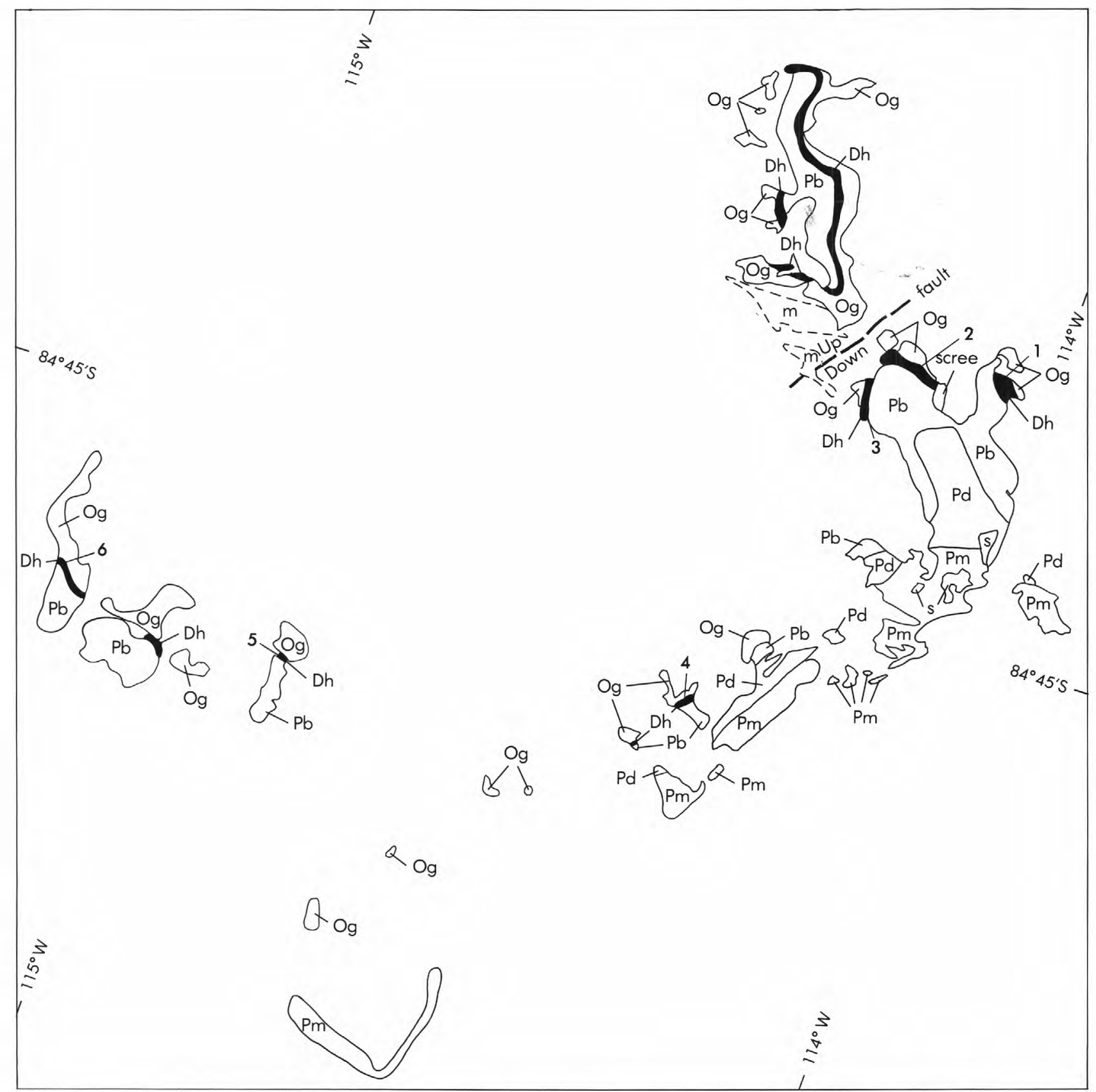

Figure 2. Continued. 

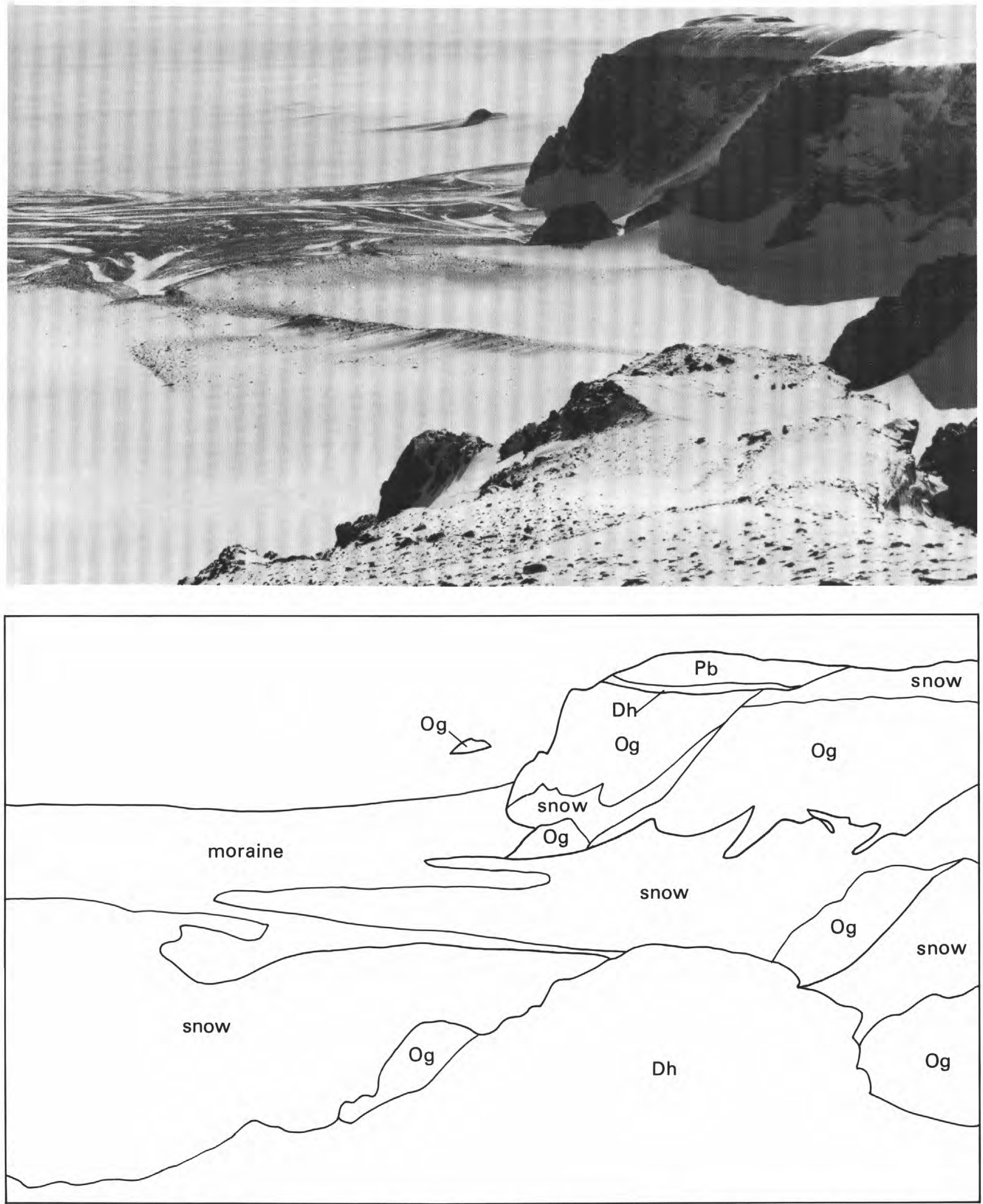

Figure 3. Photograph and sketch showing the predominantly north-facing escarpment along the Ohio Range. The Lower Devonian Horlick Formation (Dh) unconformably overlies the Ordovician granite $(\mathrm{Og})$ and is overlain by
Permian and Carboniferous glacial and outwash sediment of the Buckeye Tillite $(\mathrm{Pb})$. Looking northward toward Darling Ridge from Lackey Ridge. West Antarctica is in the background. 
to participate in the expedition and the generous support of the Antarctic Division of the New Zealand Division of Scientific and Industrial Research, the Canterbury Museum Trust Board, the R.S. Allan Trust Fund, the U.S. National Science Foundation, and the USGS. The hospitable and efficient staff at Scott Base, where we stayed before and after the expedition, and the U.S. Navy's skilled loading and flying crews, who ferried us to and from the Ohio Range, were also important to the project. James Schopf (Ohio State University, deceased, 1979) and George Doumani (Library of Congress) provided unpublished information and encouragement.

\section{DESCRIPTION OF THE HORLICK FORMATION}

\section{Stratigraphic and Structural Setting}

The Horlick Formation was deposited on a nearly flat granitic surface. The unconformity at the base of the Horlick represents a break in the geologic record of about 100 m.y. Overlying the Horlick is the Permian and Carboniferous Buckeye Tillite, which records multiple glacial events in alternating ice-override and outwash deposits. Broad erosional channels (having $50 \mathrm{~m}$ of relief in $5 \mathrm{~km}$ ) truncate the top of the Horlick, and the Horlick is completely absent from some places such as Otago Spur and the west end of Lackey Ridge (figs. 1, 2). The Horlick consists of alternating beds of fossiliferous, massive to trough-crossbedded sandstone; plane-laminated and rippled, fine-grained sandstone; bioturbated, poorly sorted, fine- to coarse-grained sandstone; and shaly mudstone.

The Horlick Formation is thickest $(50 \mathrm{~m})$ on Discovery Ridge, is thinnest (10 m) on Lackey Ridge, and is of intermediate thickness $(30 \mathrm{~m})$ on Darling Ridge (fig. 1). This westward thinning appears to be due mainly to erosion associated with or prior to deposition of the Buckeye Tillite rather than to the $100-\mathrm{m}$ increase in the altitude of the top of basement from east to west (fig. 1), which apparently resulted from gentle post-Devonian tilting. Significant relief on the basement surface at the time of deposition of the Horlick Formation is unlikely because of its thin but laterally extensive distribution and the lack of evidence for a major eustatic rise in sea level that might account for deposition over a range of elevations.

We found no direct evidence that accumulation of Horlick Formation sediment was associated with faulting, but some of Long's (1965) small faults coincide with the edges of channels we noted in the Horlick Formation, and they may reflect growth of faults during deposition. Later faulting has taken place in the Ohio Range, however, and is the cause of the vertical offset of Treves Butte with respect to Discovery Ridge (fig. 1). Faulting may also have been part of the process that raised the Ohio Range above the Polar Plateau (Long, 1965). Small, high-angle faults cut Devonian and later rocks, and some could be traced into the granite; however, no observed faults were exclusive to the granite.

The predominant sandstone minerals-quartz and feldspar-suggest a granitic source, such as the rocks underlying the Horlick. Chlorite (or its precursor), the main mineral in the finer grained part of the Horlick, must have been derived from mafic rocks such as (1) those in the Hart and Stewart Hills $200 \mathrm{~km}$ to the northeast or (2) the local metamorphic country rock, now found only as mafic xenoliths in the granite.

Brachiopods (Australospirifer and straight-ribbed Pleurothyrella) indicate that the Horlick Formation is part of the upper Lower Devonian (Emsian) Malvinokaffric Province, as are units in South America and southern Africa (Boucot and others, 1969). Less closely allied is New Zealand's Reefton Group, which shares the distinctive brachiopod Tanerhynchia with the Horlick Formation but contains a Pleurothyrella having bifurcating instead of straight ribs. The Malvinokaffric Province evolved from the previously established Eastern North American Province and is distinct from other Devonian zoogeographic provinces (Boucot and others, 1969). Deposits in the Malvinokaffric Province of South Africa that are inferred to be of glacial origin suggest that the Early Devonian flora and fauna existed in a cool climate and suggest that the global temperature distribution then was similar to that today (Boucot and others, 1963; Boucot, 1975; Edwards, 1973).

\section{Detailed Lithostratigraphy Determined from Measured Sections}

The Horlick Formation is described in terms of nine lithofacies in measured sections at fifteen locations (fig. 1). The lithofacies, first presented in an earlier paper (Bradshaw and McCartan, 1983), were determined on the basis of seven characteristics observed in the field: grain size, sorting, bed thickness, crossbedding and other physical sedimentary structures, biogenic structures, fossil content, and mineralogy. Some original lithofacies definitions are used unchanged in the present paper, and others are slightly modified on the basis of petrologic data. The definitions of the lithofacies are summarized in table 1 . Lithofacies 1 occurs only at the base of the Horlick Formation; lithofacies 8, restricted to the top of the formation at only two sections, apparently was eroded from many sections prior to deposition of the Buckeye Tillite. Lithofacies 9 is present only in section 6, where it is the entire formation. Lithofacies 2-7 are repeated throughout the Horlick and are found locally in channels or in gradational contact with other facies.

The Horlick Formation consists mainly of subarkosic arenite and chloritic mudstone, minor amounts of feldspathic wacke, and various sandstones containing a large proportion of secondary calcite (table 2; compositional nomenclature modified from Dott, 1964, and Petti- 
Table 1. Lithofacies 1-9 of the Horlick Formation

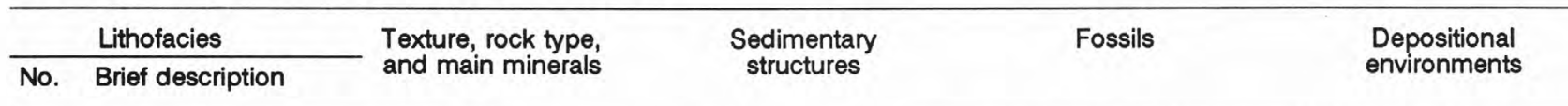

Coarse-grained
micaceous quartz
arenite to

arenite to

fine-grained

conglomerate.

Quartz is the main

mineral; feldspar

content is less than 5

percent at many

localities; secondary

calcite is notable.

2 Pleurothyrella beds

Medium- to coarsegrained, poorly sorted subarkosic arenite. Quartz is the main mineral; feldspar content is more than 10 percent.

3 Interbedded shale, mudstone, and sandstone; shale and mudstone abundant.

4 Planar-laminated or rippled sandstone.

5 Interbedded sandstone, mudstone, and shale; sandstone dominant.

6 Phosphate beds

$7 \quad$ Tentaculites beds

Mudstone, shale, fineto coarse-grained subarkosic arenite, calcareous wacke, and a few pebble layers. Chlorite and quartz are the main minerals; feldspar content is more than 10 percent.

Mainly fine-grained subarkosic arenite or feldspathic wacke. Quartz is the main mineral; mica is notable; at some localities, plagioclase is more abundant than potassium feldspar.

Medium- to coarsegrained subarkosic arenite containing small pebbles. Quartz is the main mineral; chlorite matrix is common; feldspar content is more than 10 percent.

Fine- to mediumgrained subarkosic arenite. Quartz is the main mineral; feldspar and chlorite contents are moderate; phosphatic clasts are common.

Fine- to medium-

Trough crossbeds indi-
cating onshore, off-
shore, and longshore
current directions;
trough crossbeds are
$20-30 \mathrm{~cm}$ wide,
$10-30 \mathrm{~cm}$ thick, $1 \mathrm{~m}$
long; channeled
base.

Massive and bioturbated beds, rare channels, several shell beds. grained subarkosic arenite and quartzose limestone. Quartz is common, but feldspar is rare.

Small crossbeds, small channels, ripples, and other indicators of onshore, offshore, and longshore current directions; shale and mudstone alternating with sandstone; fine-grained beds making up $30-50$ percent of the lithofacies; shell-hash layers.

Interference ripples, planar laminations.

Trough crossbeds, channels, and other indicators of mostly offshore and longshore current directions; alternations of sandstone and mudstone or shale in which more than 50 percent and typically more than 90 percent of the unit is sandstone; lithified mudchip conglomerates. beds are a few centimeters thick.
Crude alignment of

\section{Rare fossils: Orbicu- \\ loidea, Pleurothyrella, \\ bones; straight verti- \\ cal burrows less than \\ $1 \mathrm{~cm}$ in diameter.}

\section{Unbarred subtidal}

shoreface.

Abundant Pleurothy-

rella; common

Modiomorpha, Nucu-

lites; fewer Orbicu-

loidea, Lingula,

Rosselia, and

arcuate, lithified-mud-

filled burrows of filter feeders.

Layers of broken shells; few burrows (Asterosoma in one sandstone bed).

Walking tracks of arthropods, infilled tubes and grooves; few body fossils.

Massive beds; most

Trilobites, bone fragments, and inarticulate brachiopods common. Tentaculites.
Fossils rare to absent
Tentaculites and Nuculites dominant; bellerophontids and Nuculoidea less abundant.
Inner shelf.
Steeper parts of subtidal bars.

Inactive shoreface troughs; seaward flanks of sand tongues.

Bar tops.

Steeper parts of subtidal
bars; sand tongues above wave base.

Seaward flanks of sand tongues; inner shelf. 
Table 1. Lithofacies 1-9 of the Horlick Formation-Continued

\begin{tabular}{|c|c|c|c|c|c|}
\hline & Lithofacies & \multirow{2}{*}{$\begin{array}{l}\text { Texture, rock type, } \\
\text { and main minerals }\end{array}$} & \multirow{2}{*}{$\begin{array}{l}\text { Sedimentary } \\
\text { structures }\end{array}$} & \multirow[t]{2}{*}{ Fossils } & \multirow{2}{*}{$\begin{array}{l}\text { Depositional } \\
\text { environments }\end{array}$} \\
\hline No. & Brief description & & & & \\
\hline 8 & Spiriferid beds & $\begin{array}{l}\text { Poorly sorted, coarse- } \\
\text { to medium-grained, } \\
\text { silica-cemented } \\
\text { subarkosic arenite to } \\
\text { feldspathic wacke. } \\
\text { Feldspar content is } \\
\text { more than } 20 \text { per- } \\
\text { cent; chlorite matrix } \\
\text { makes up more than } \\
40 \text { percent of the } \\
\text { rock. }\end{array}$ & $\begin{array}{l}\text { Massive and } \\
\text { thoroughly biotur- } \\
\text { bated beds. }\end{array}$ & $\begin{array}{l}\text { Abundant spiriferids } \\
\text { and Rosselia; some } \\
\text { other body and trace } \\
\text { fossils. }\end{array}$ & $\begin{array}{l}\text { Steeper parts of subtidal } \\
\text { bars. }\end{array}$ \\
\hline 9 & Fluvial beds & $\begin{array}{l}\text { Coarse-grained, peb- } \\
\text { bly arkosic arenite. } \\
\text { Quartz is the main } \\
\text { mineral; feldspar } \\
\text { content is more than } \\
10 \text { percent. }\end{array}$ & $\begin{array}{l}\text { Climbing backflow rip- } \\
\text { ples, channels. }\end{array}$ & No fossils & Fluvial channel. \\
\hline
\end{tabular}

Table 2. Mineralogy of Horlick Formation sandstone and source rock

[For thin sections A and C-K, 200-400 points were counted in each section by McCartan; B was analyzed by Karl Kellogg and Ahmed El Basli. Values are number percentages. Sandstone classification is modified from Dott (1964) and Pettijohn and others (1973). tr, less than 5 percent; N/A, not applicable]

\begin{tabular}{|c|c|c|c|c|c|c|c|c|c|c|c|}
\hline Thin section . . . . . . . . . & $A^{1}$ & $\mathrm{~B}^{2}$ & C & D & $E$ & $F^{3}$ & G & $\mathrm{H}^{4}$ & I & $\mathrm{J}$ & $\mathrm{K}^{5}$ \\
\hline $\begin{array}{l}\text { Measured section .... } \\
\text { Altitude above granite (m) }\end{array}$ & $\begin{array}{l}1 \\
0\end{array}$ & $\begin{array}{l}4 \\
0\end{array}$ & $\begin{array}{l}1 \\
1\end{array}$ & $\begin{array}{l}1 \\
2\end{array}$ & $\begin{array}{c}1 \\
13\end{array}$ & $\begin{array}{l}1 \\
3\end{array}$ & $\begin{array}{c}1 \\
36\end{array}$ & $\begin{array}{c}1 \\
19\end{array}$ & $\begin{array}{c}1 \\
45\end{array}$ & $\begin{array}{c}7 \\
11\end{array}$ & $\begin{array}{c}7 \\
12\end{array}$ \\
\hline Rock type. .......... & granite & granite & $\begin{array}{l}\text { quartz } \\
\text { arenite }\end{array}$ & $\begin{array}{l}\text { calcar- } \\
\text { eous } \\
\text { quartz } \\
\text { arenite }\end{array}$ & $\begin{array}{l}\text { subar- } \\
\text { kosic } \\
\text { arenite }\end{array}$ & $\begin{array}{l}\text { subar- } \\
\text { kosic } \\
\text { arenite }\end{array}$ & $\begin{array}{l}\text { subar- } \\
\text { kosic } \\
\text { arenite }\end{array}$ & $\begin{array}{l}\text { quartz- } \\
\text { ose } \\
\text { lime- } \\
\text { stone }\end{array}$ & $\begin{array}{l}\text { feld- } \\
\text { spathic } \\
\text { wacke }\end{array}$ & $\begin{array}{l}\text { feld- } \\
\text { spathic } \\
\text { wacke }\end{array}$ & $\begin{array}{l}\text { calcareous } \\
\text { wacke }\end{array}$ \\
\hline Lithofacies . . . . . . . . . & N/A & N/A & 1 & 1 & 4 & 2 & 4 & 7 & 8 & 4 & 3 \\
\hline \multicolumn{12}{|l|}{ Dominant grains: } \\
\hline 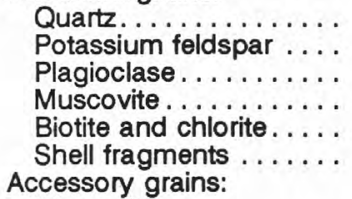 & $\begin{array}{r}44 \\
20 \\
29 \\
\mathrm{tr} \\
6 \\
0\end{array}$ & $\begin{array}{r}29 \\
31 \\
32 \\
1 \\
5 \\
0\end{array}$ & $\begin{array}{r}88 \\
0 \\
0 \\
5 \\
6 \\
1\end{array}$ & $\begin{array}{r}61 \\
5 \\
\mathrm{tr} \\
\mathrm{tr} \\
1 \\
0\end{array}$ & $\begin{array}{r}52 \\
12 \\
\mathrm{tr} \\
18 \\
4 \\
9\end{array}$ & $\begin{array}{r}70 \\
20 \\
1 \\
0 \\
2 \\
1\end{array}$ & $\begin{array}{r}58 \\
10 \\
12 \\
15 \\
1 \\
0\end{array}$ & $\begin{array}{r}10 \\
0 \\
0 \\
2 \\
0 \\
15\end{array}$ & $\begin{array}{r}30 \\
20 \\
3 \\
1 \\
0 \\
0\end{array}$ & $\begin{array}{r}58 \\
5 \\
10 \\
\mathrm{tr} \\
0 \\
1\end{array}$ & $\begin{array}{r}33 \\
13 \\
1 \\
1 \\
1 \\
10\end{array}$ \\
\hline 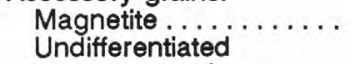 & 0 & 1 & 0 & 0 & 2 & 0 & 0 & 0 & 0 & 0 & 0 \\
\hline $\begin{array}{l}\text { opaque grains . . . . . } \\
\text { Epidote...... . . . . . } \\
\text { Sphene. . . . . . . . . . } \\
\text { Tourmaline . . . . . . . } \\
\text { Polycrystalline quartz }\end{array}$ & $\begin{array}{l}0 \\
0 \\
1 \\
0\end{array}$ & $\begin{array}{r}0 \\
t r \\
0 \\
0\end{array}$ & $\begin{array}{l}0 \\
0 \\
0 \\
0\end{array}$ & $\begin{array}{l}0 \\
0 \\
0 \\
0\end{array}$ & $\begin{array}{l}0 \\
t r \\
t r \\
t r\end{array}$ & $\begin{array}{l}0 \\
0 \\
0 \\
0\end{array}$ & $\begin{array}{l}2 \\
1 \\
0 \\
0\end{array}$ & $\begin{array}{l}3 \\
0 \\
0 \\
0\end{array}$ & $\begin{array}{l}0 \\
0 \\
0 \\
0\end{array}$ & $\begin{array}{r}0 \\
0 \\
\text { tr } \\
0\end{array}$ & $\begin{array}{l}2 \\
0 \\
0 \\
0\end{array}$ \\
\hline $\begin{array}{l}\text { and chalcedony } \ldots . . . \\
\text { Fine-grained granitic }\end{array}$ & 0 & 0 & 0 & 0 & 0 & 6 & 0 & 0 & 1 & 0 & 0 \\
\hline $\begin{array}{l}\text { rock fragments ....... } \\
\text { Matrix: }\end{array}$ & 0 & 0 & 0 & 0 & 2 & 0 & $t r$ & 0 & $t r$ & 0 & 0 \\
\hline $\begin{array}{l}\text { Mainly chlorite }{ }^{8} \ldots \ldots \ldots \\
\text { Mainly calcite } \ldots \ldots \ldots\end{array}$ & $\begin{array}{l}0 \\
0\end{array}$ & $\begin{array}{l}0 \\
0\end{array}$ & $\begin{array}{l}0 \\
0\end{array}$ & $\begin{array}{r}0 \\
32\end{array}$ & $\begin{array}{l}0 \\
0\end{array}$ & $\begin{array}{r}\mathbf{t r} \\
0\end{array}$ & $\begin{array}{l}0 \\
0\end{array}$ & $\begin{array}{r}0 \\
69\end{array}$ & $\begin{array}{r}45 \\
0\end{array}$ & $\begin{array}{r}26 \\
0\end{array}$ & $\begin{array}{r}7 \\
31\end{array}$ \\
\hline
\end{tabular}

1 Thin section A contains 1 percent diopside.

2 Thin section B contains traces of allanite, fluorite, and zircon.

${ }^{3}$ In thin section F, calcile has replaced some orthoclase; the 20 percent given for potassium feldspar includes 7 percent calcite.

4 Silicified calcite tubes make up 2 percent of thin section $\mathrm{H}$.

5 Thin section $K$ contains a trace of spinel.

${ }^{B} \mathrm{X}$-ray diffraction indicates that matrix chlorte is iron chlorite. 
john and others, 1973). In this report on the Horlick, "subarkosic arenite" means sandstone consisting of as much as 95 percent quartz, 5-25 percent feldspar, and almost no rock fragments; "wacke" means rocks in which more than 15 percent of the material is finer than $30 \mu \mathrm{m}$; and "limestone" means rocks in which more than 50 percent of the calcite is of detrital (biogenic) or secondary origin. "Calcareous matrix" includes detrital calcareous mud as well as true cement and recrystallized calcite mud. Sand-sized grains in the Horlick Formation (listed in order of decreasing abundance) are quartz; feldspar; calcite shell fragments; muscovite; biotite and chlorite; accessory minerals such as sphene, pyrite, magnetite, tourmaline, epidote, diopside, and polycrystalline quartz; and finegrained granitic rock fragments. Rare sand-sized patches of chlorite probably replaced fine-grained mafic minerals in shale, mudstone, and the matrix of sandstone. Most of the quartz and feldspar grains are angular to subrounded.

Stratigraphic sections, presented in groups from east to west, were measured through the Horlick Formation at 15 localities representing almost every spur along the Ohio Range (fig. 2). The Horlick is absent from Mt. Schopf, and outlying Treves Butte was not visited because of difficult access. Figure 4 is a textural summary diagram of all the measured sections. Petrology and lithofacies of the first section are described below in detail (fig. 5). The other sections are presented in figures $6,15,16$, and 17 , but are discussed only briefly in the text.

\section{Section 1, Discovery Ridge}

The first section through the Horlick Formation, measured on the east spur of Discovery Ridge, is about $47 \mathrm{~m}$ thick (figs. 1, 5). It is a sequence of fine- to coarse-grained sandstone beds interbedded with mudstone and shale; marine body fossils and trace fossils occur throughout.

Lithofacies 1.-Lithofacies 1, at the base of section 1 , unconformably overlies the granite and is $2 \mathrm{~m}$ thick. It consists of trough-crossbedded, coarse-grained, micaceous quartz arenite (figs. $7 A, B$ ) and fine-grained conglomerate. The crossbed sets are $10-30 \mathrm{~cm}$ thick and fill small channels in the surface of the granite (fig. 8). Crossbeds dip in several directions. Lithofacies 1 is distinguished from overlying sandstones by its low feldspar content and lack of body fossils (table 2, thin section C). Vertical burrows less than $1 \mathrm{~cm}$ in diameter record the presence of organisms during or shortly after deposition of the sediment. A sample near the top of lithofacies 1 contains 32 percent calcite cement, which was probably recrystallized from fine-grained shell fragments (table 2, thin section D). Rare lithified mud chips and very minor, thin, discontinuous siltstone are also present.

The texture, structures, and widespread distribution of lithofacies 1 in the Ohio Range and its presence only at the base of the Horlick suggest that it was deposited prior to the development of large-scale offshore bars that characterize the remainder of the Horlick.

Lithofacies 2. - In section 1, about $1.1 \mathrm{~m}$ of mediumto coarse-grained, bioturbated sandstone containing abundant Pleurothyrella brachiopods and other fossils (figs. 5, $9 A, B$ ) overlies the basal sandstone and is assigned to lithofacies 2. Primary bedding structures have been destroyed by bioturbation. Unlike the basal sandstone, lithofacies 2 occurs in several places in section 1, making up about 13 percent of the Horlick Formation at this locality. In most places, it is within or adjacent to interbedded sandstone and shale. Lithofacies 2 is a somewhat poorly sorted, subarkosic arenite containing three times as much feldspar as the underlying basal sandstone (table 2, thin section F). The Pleurothyrella beds generally contain little calcareous matrix or cement, despite abundant calcareous fossils; in contrast, the basal sandstone contains a high proportion of secondary calcite in places, but has few fossils.

Besides Pleurothyrella, lesser numbers of other shallow-water forms, such as the mollusk Modiomorpha and the inarticulate brachiopods Orbiculoidea and Lingula, are present. Articulated shells were found in some beds; coarse shell fragments are concentrated at the tops of beds. Lithofacies 2 appears to have been deposited in positions intermediate between the tops of topographic highs and the mud-trapping lows.

Lithofacies 3.-Lithofacies 3 makes up about 40 percent of section 1 (figs. $5,10 \mathrm{~A}-\mathrm{C}$ ). It is fine- to coarsegrained, massive to trough-crossbedded sandstone alternating with mudstone or shale beds in which fine-grained material is one-third to one-half of the unit. The shale and mudstone are chloritic, and, in outcrop, they are commonly indented or form shallow slopes covered with sandstone blocks from the overhanging cliffs. The sandstone contains more than 10 percent feldspar and significant secondary chlorite and calcite in some areas and ranges from fossil-bearing subarkosic arenite to calcareous wacke.

At several places on Discovery Ridge, including the vicinity of section 1 , sequences of interbedded sandstone and shale several meters thick grade laterally into the crossbedded sandstone of lithofacies 5 or vertically into the planar-laminated and rippled sandstone of lithofacies 4. Sandstone-filled channels also commonly truncate the interbedded lithofacies. This lateral variability precludes precise correlation among sections and reflects the complex water movements that prevailed during the time of Horlick deposition. Shales include occasional wisps of fine sandstone, and some fine sandstone beds as much as a few centimeters thick have clay drapes over stacked ripples. A few beds of pebbles or shell hash that contain bone fragments are present; they are 1-2 cm thick, are locally crossbedded, and are probably storm deposits. 


\section{EXPLANATION}

Shale, mudstone, siltstone

Fine-grained sandstone

Medium-grained sandstone

Coarse-grained sandstone, no pebbles

Medium- to coarse-grained sandstone containing pebbles

Fine-grained conglomerate

\section{METERS}

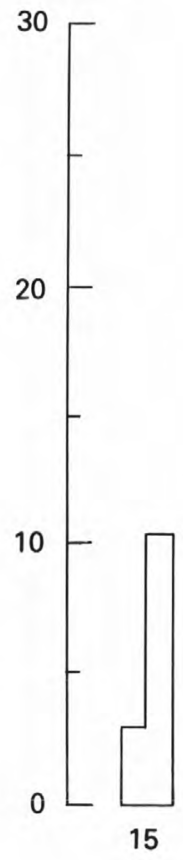

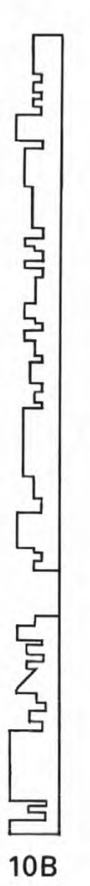
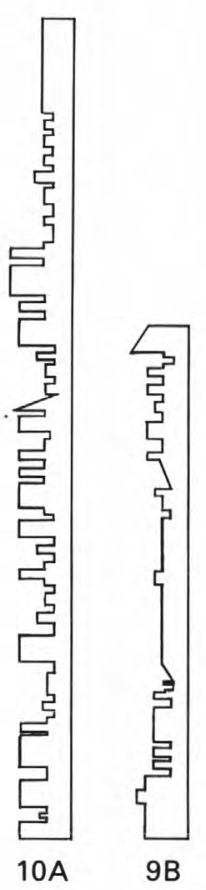

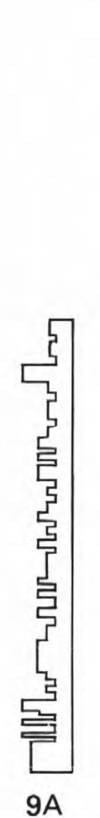

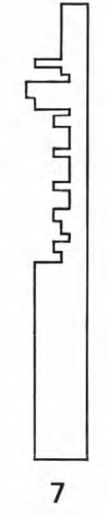

Figure 4. Textures of measured sections 1-15 through the Horlick Formation, Ohio Range. Locations of sections are indicated in figure 1; in this diagram, east is generally to the right.
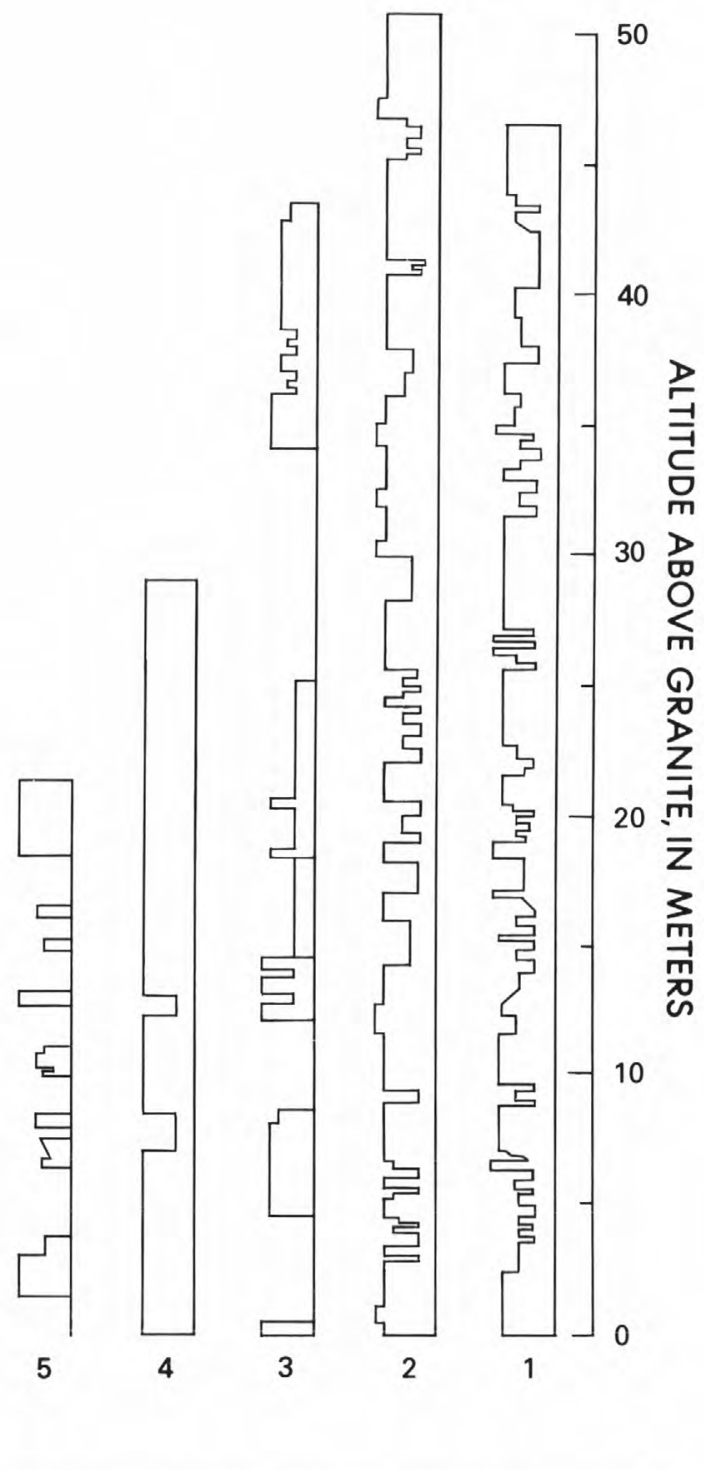

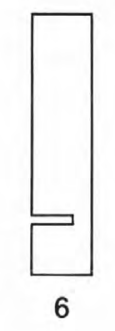

\section{MEASURED SECTIONS}

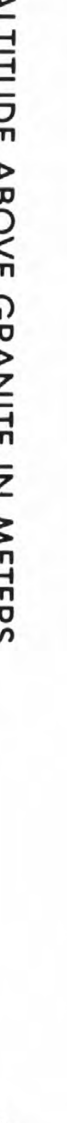




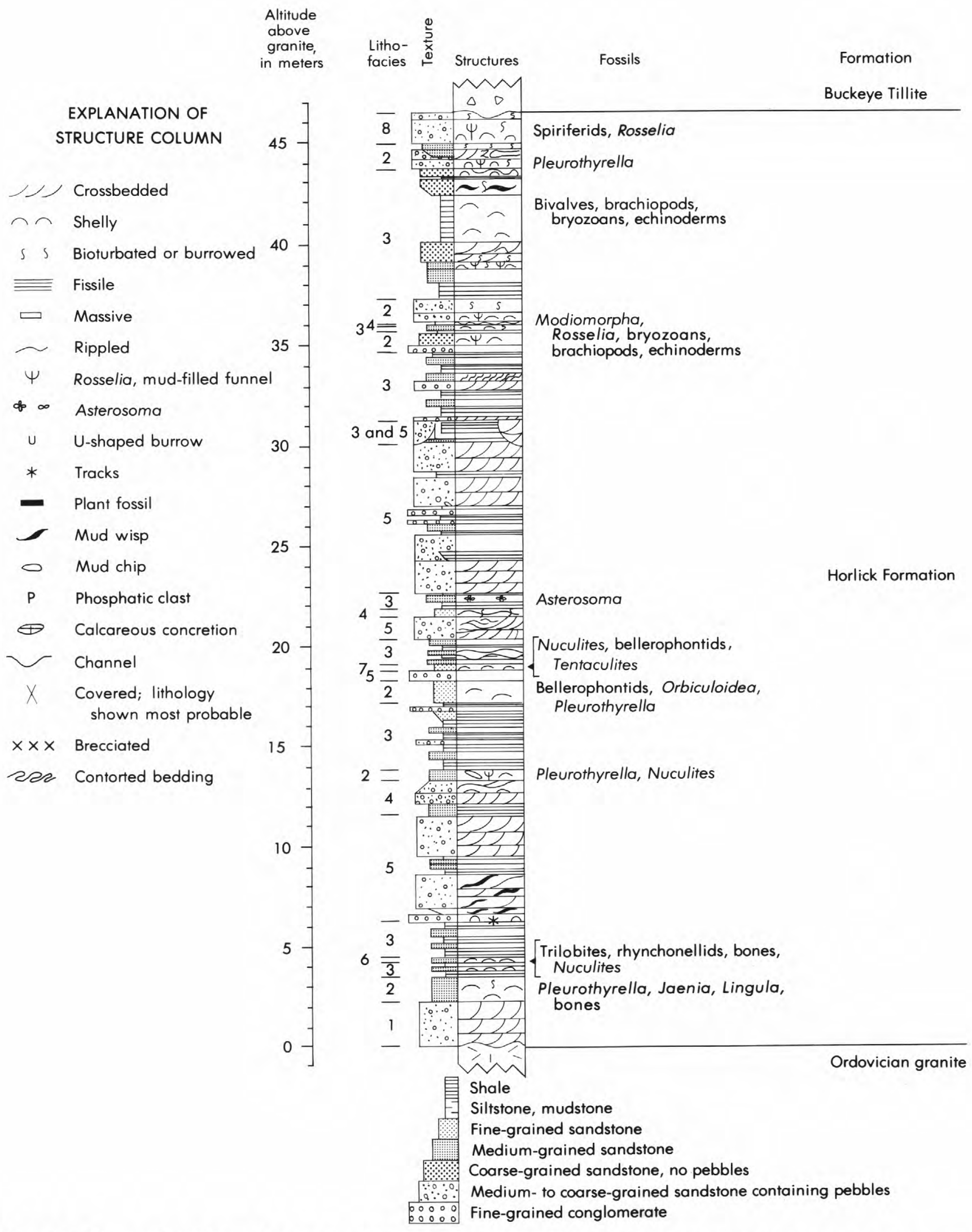

Figure 5. Measured section 1 through the Horlick Formation, Discovery Ridge (figs. 1, 2). Lithofacies 1-8 (table 1) are discussed in text. Some of the most abundant fossils are listed to the right of the column. The explanation of the structure column also serves figures $6,15,16$, and 17 ; not all the symbols are used in each figure. 


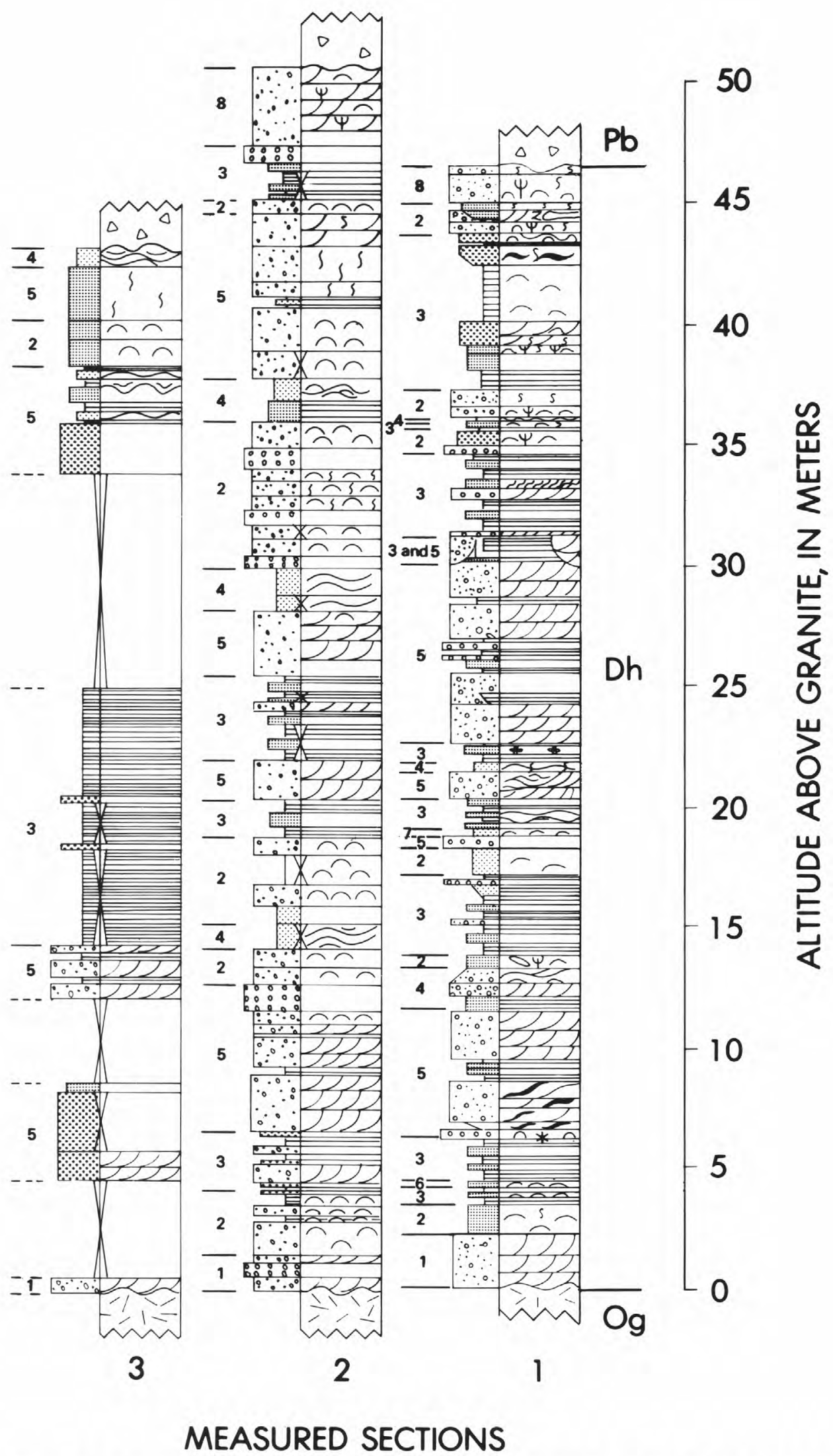

Figure 6. Measured sections 1-3, Discovery Ridge. Texture and structure symbols are explained in figure 5 . Pb, Buckeye Tillite; Dh, Horlick Formation; Og, Ordovician granite. Section 1 is repeated for comparison. 


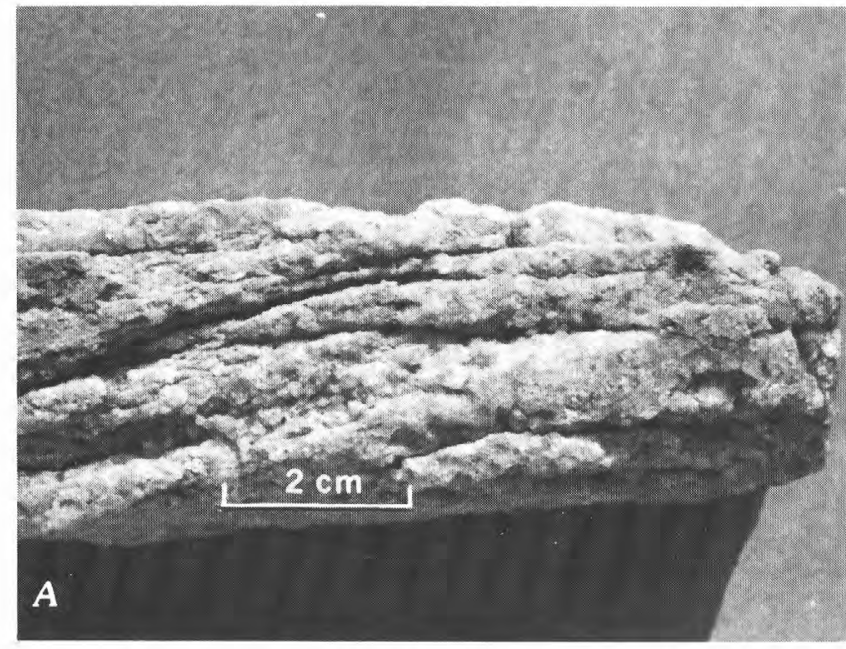

Figure 7. A sample of lithofacies 1, crossbedded, coarsegrained quartz arenite, from basal beds of the Horlick Formation in measured section 1 on Discovery Ridge. $A$, Hand specimen. $B$, Thin section $C$ (table 2 ) of specimen shown

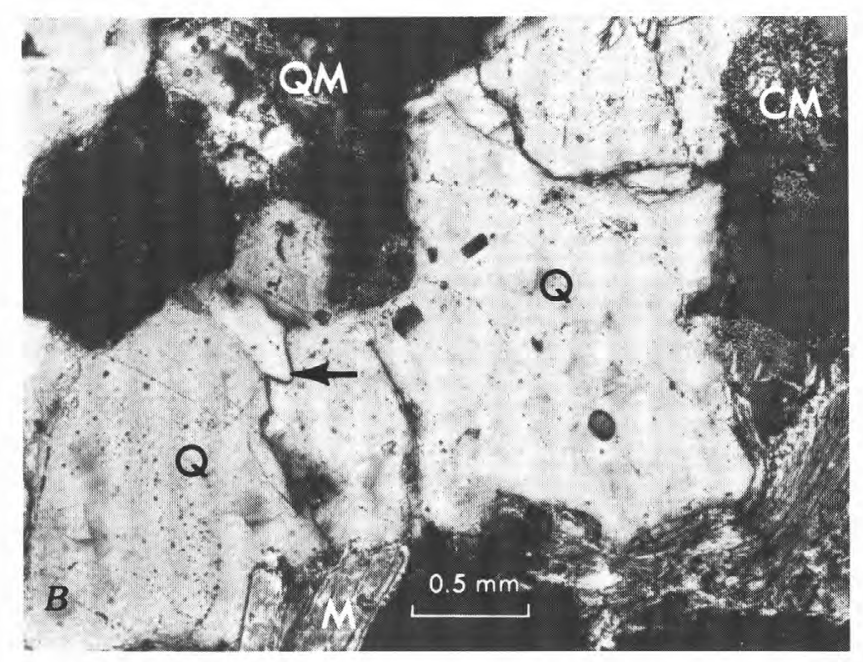

in figure $7 A$; crossed polarizers. $\mathrm{CM}$, chlorite-muscovite aggregate; $M$, muscovite, euhedral and bent crystals; $Q$, quartz (note pyramid terminations at arrow); QM, quartzmuscovite aggregate.

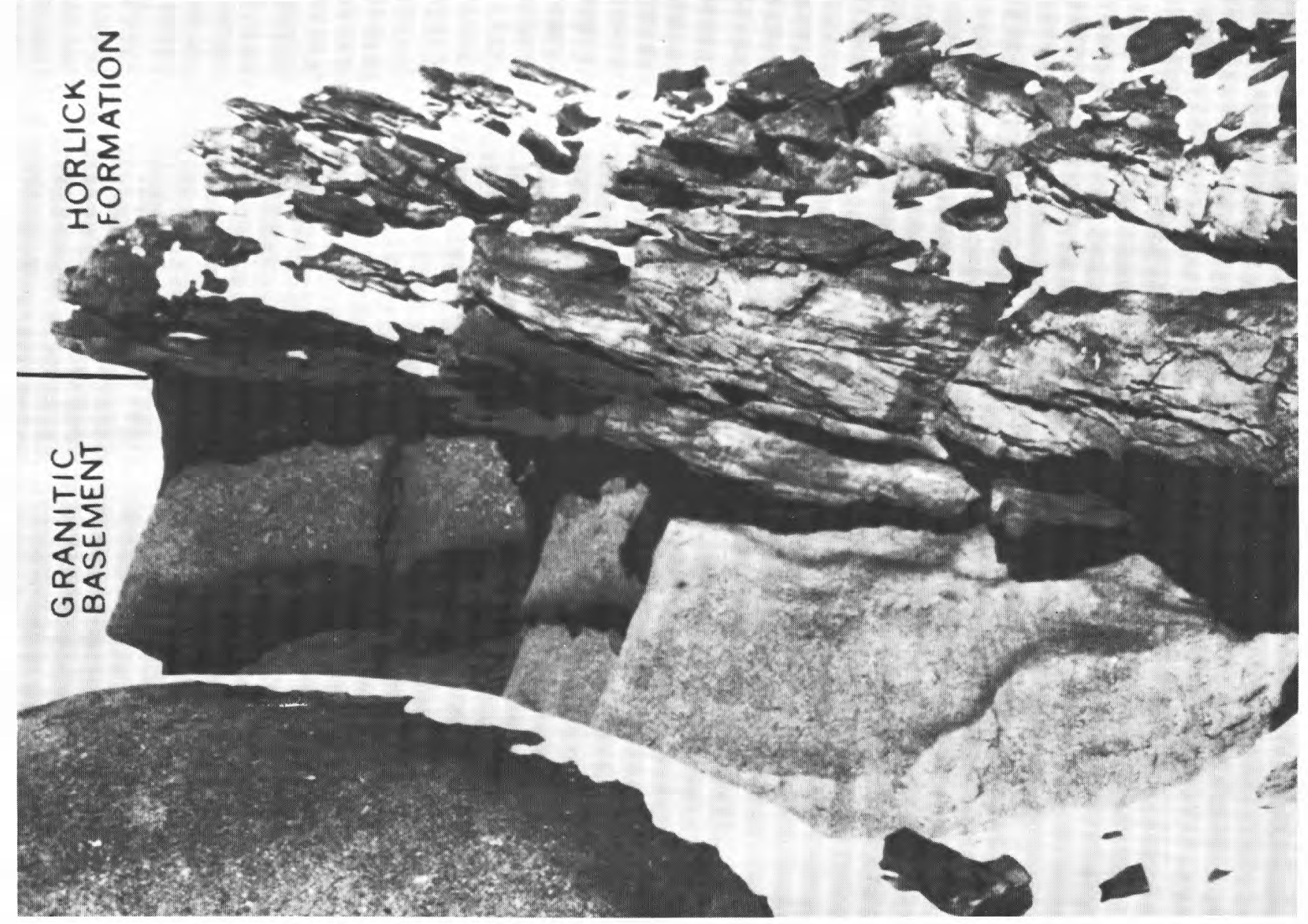

Figure 8. Base of Horlick Formation at Lackey Ridge (fig.1). Outcrop is about $2.5 \mathrm{~m}$ high. 
Psilophyte plant fragments are notable in a few of the shale beds, especially near the base of the Horlick. Whole shells and bioturbation are rare, suggesting that the depositional environments, which appear to have been inactive shoreface troughs and the seaward parts of sand tongues, were inhospitable to most shelled or burrowing organisms.

Lithofacies 4. - Lithofacies 4 is a distinctive fine- to medium-grained sandstone containing planar laminations or interference ripples. It makes up less than 1 percent of section 1 but is present in at least three parts of the section (figs. 5, 11A-F). The interference-rippled sandstone, which is generally unfossiliferous subarkosic arenite or feldspathic wacke, in some places grades upward into planar-laminated sandstone that is also subarkosic arenite. The interference-rippled sandstone has about 20 percent feldspar (table 2, thin section $\mathrm{G}$ ). This is the only sandstone in which plagioclase is more abundant than potassium feldspar, as in the granite. The planar-laminated sandstone is better sorted than the interference-rippled sandstone, has less feldspar, and has heavy-mineral
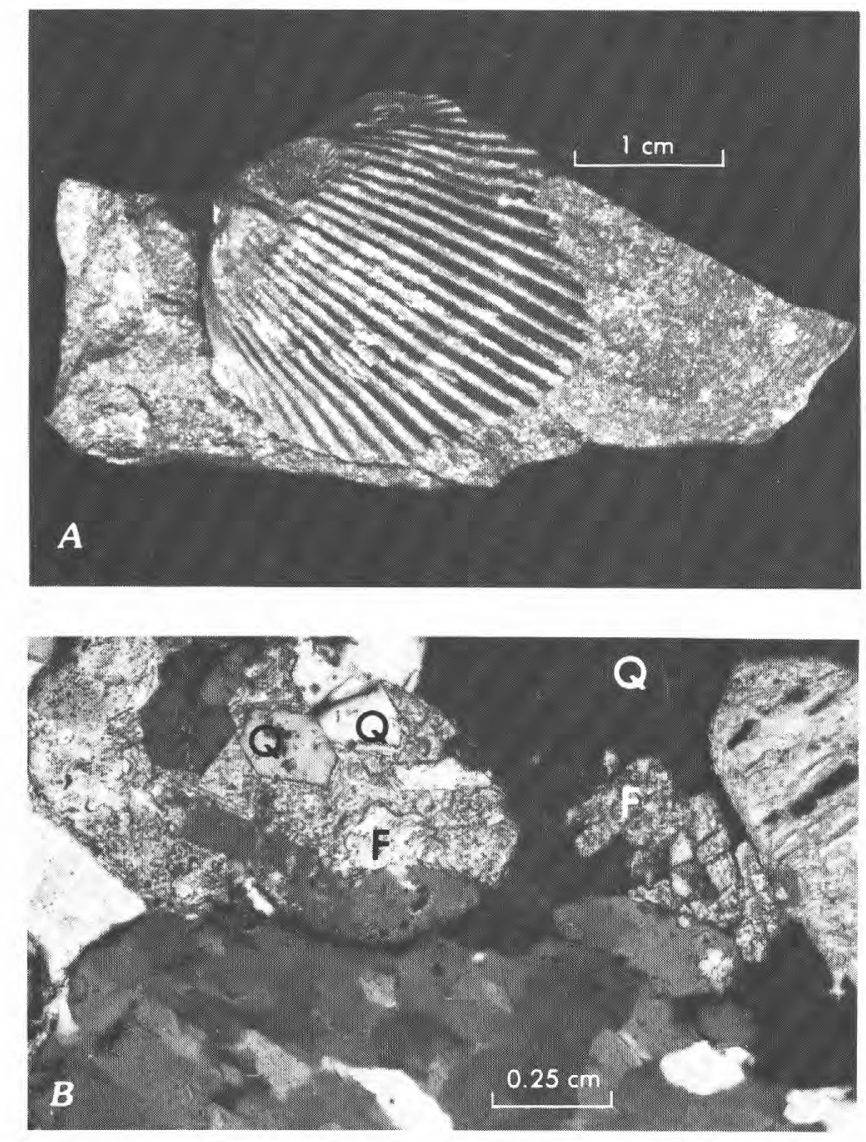

Figure 9. Samples of lithofacies 2, fossiliferous, subarkosic arenite, from above basal beds in measured section 1 on Discovery Ridge. A, Pleurothyrella. $B$, Thin section $\mathrm{F}$ (table 2), in which quartz euhedra (Q) are growing in fossil fragments $(F)$; lower part is dominated by polycrystalline quartz grain; crossed polarizers. laminae (table 2, thin section E). In section 1, the only fossils observed in lithofacies 4 are arthropod trackways and rare brachiopod shells. Planar and rippled beds generally lie above coarser, crossbedded sandstone or above beds of lithofacies 3 and, in many places, are below fossiliferous sandstone.

The coexistence of planar-laminated and rippled sandstone in the Horlick probably reflects reworking of
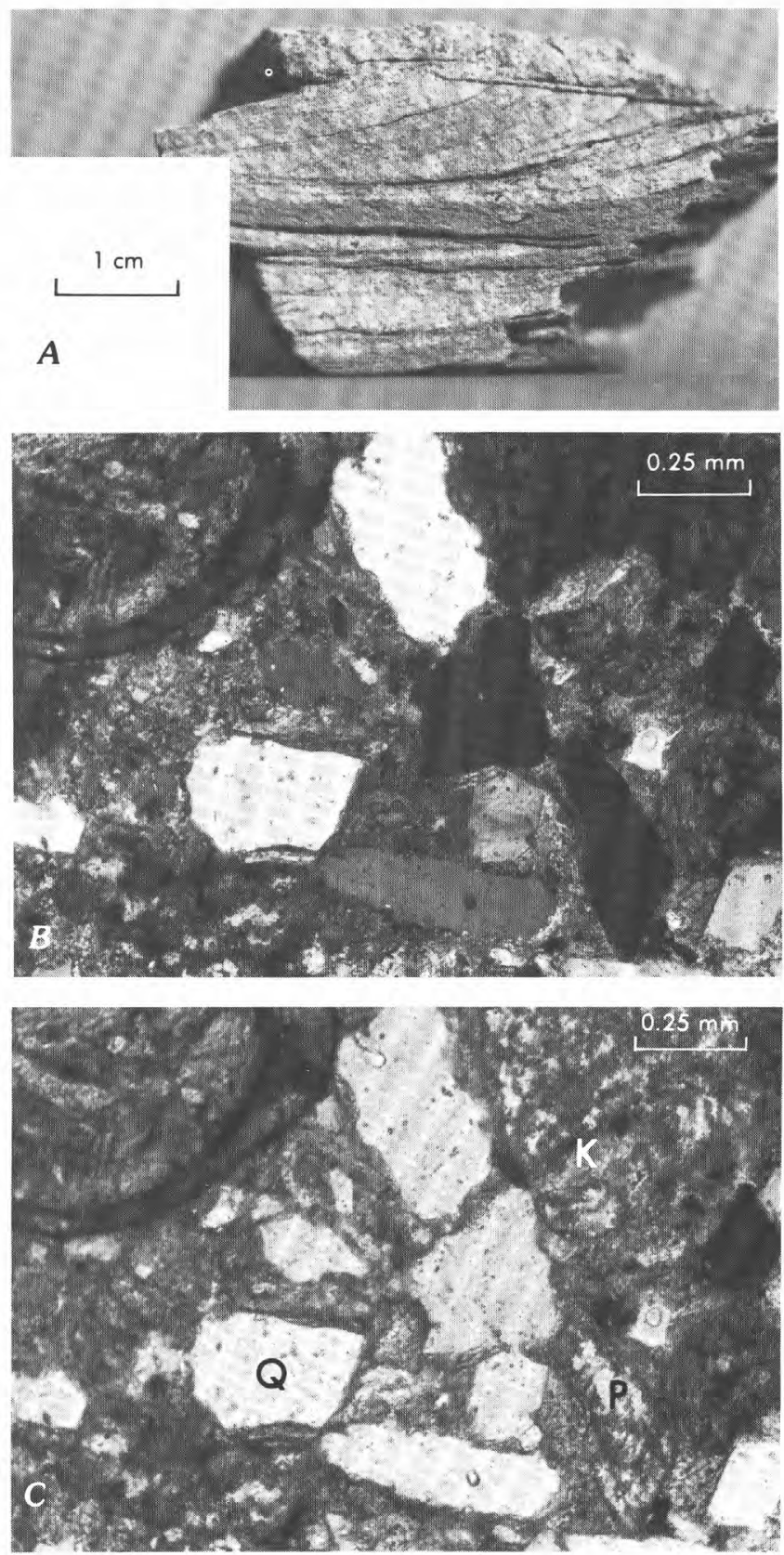

Figure 10. Samples of lithofacies 3. A, Crossbedded arenite from measured section 1; darker laminae and partings are chlorite rich. $B$ and $C$, Thin section $\mathrm{K}$ (table 2) of calcareous wacke from measured section 7 ; crossed polarizers, stage in different orientations. K, potassium feldspar; $P$, plagioclase; $Q$, quartz. The arcuate band is a cross section through a fossil; the matrix is mainly calcite with minor chlorite. 

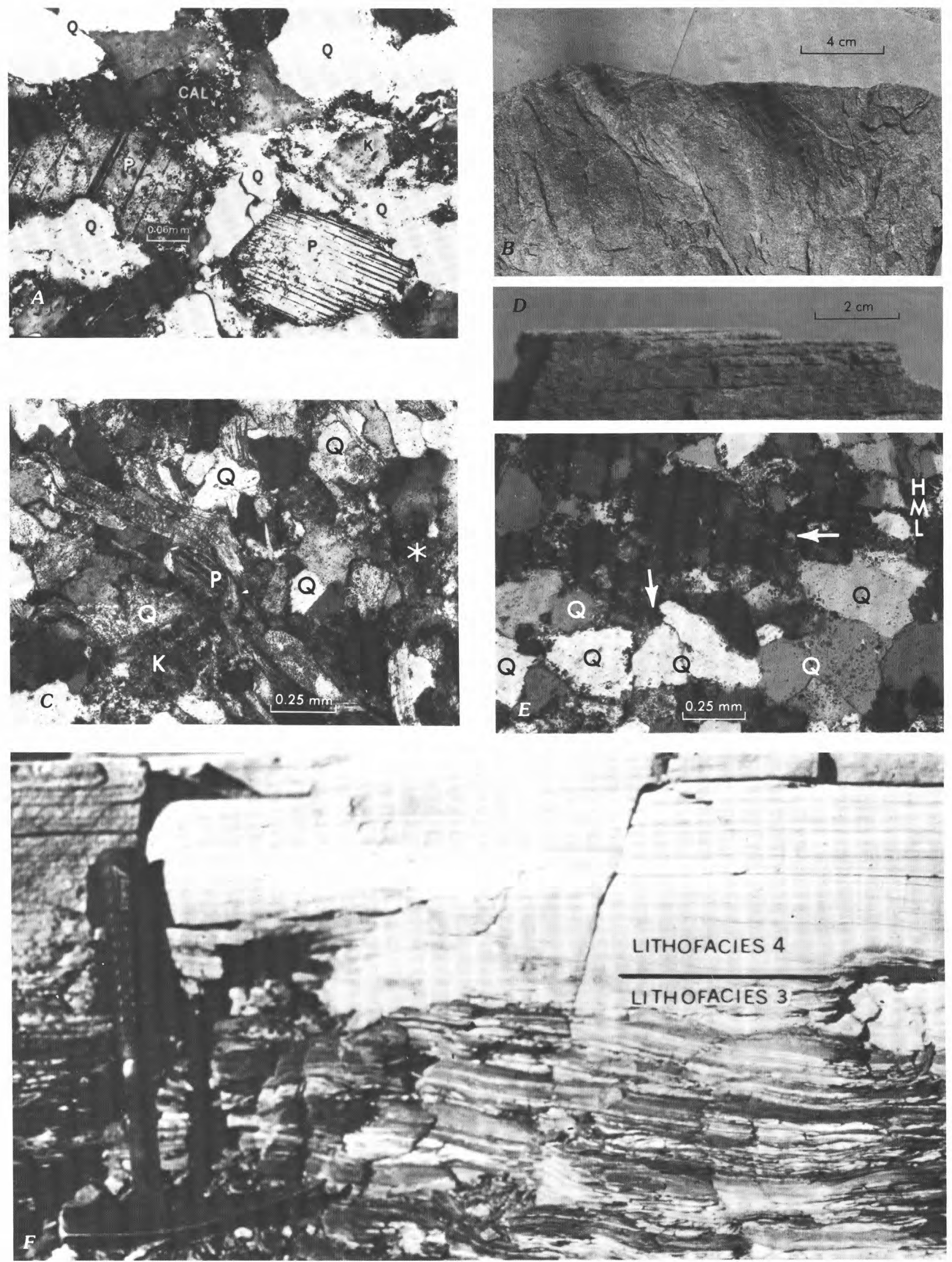

16 Petrology and Sedimentology of the Horlick Formation, Transantarctic Mountains 
bar tops by storm waves as do similar combinations in other formations (Greenwood and Mittler, 1985).

Lithofacies 5.-Lithofacies 5 is similar to lithofacies 3 as it is a sequence of alternating sandstone and shale or mudstone beds; however, lithofacies 5 is much coarser than lithofacies 3 and has at least 50 percent and usually more than 90 percent sandstone (fig. 5). This lithofacies makes up 30-35 percent of section 1 . The sandstone is a massive to crossbedded, medium- to coarse-grained, subarkosic arenite. Fossils include fish bones, fish plates, and rare brachiopod shells. A few arthropod trackways are on bedding planes at the base of section 1 . In some places, this lithofacies becomes finer grained upward. Channels are common and are filled with either shale or sandstone. Between 30 and $31 \mathrm{~m}$ above the base of section 1, a sandstone-filled channel is incised into shale.

The finer beds of lithofacies 5 were probably deposited in the same environment as those of lithofacies 3; the coarser beds reflect deposition in adjacent areas such as the steeper parts of offshore bars and sand tongues above wave base.

Lithofacies 6.-Lithofacies 6 consists of fine- to medium-grained subarkosic arenite beds (fig. 5) that are $1-20 \mathrm{~cm}$ thick. Lithofacies 6 is distinguished from lithofacies 2 by the presence of four types of phosphatic clasts-bones, trilobite fragments, inarticulate brachiopod shells, and reworked phosphatic nodules. Concentrations of the four types of phosphatic clasts suggest hiatuses at several places in the Horlick Formation (see Stephenson, 1929, for discussion of phosphate-marked hiatuses elsewhere). This lithofacies is less than 1 percent of section 1 and is present at $4.5,22$, and $27 \mathrm{~m}$ above the base; the two highest beds are too thin to be shown in figure 5 . The fine to medium grain size of the sandstone and the abundance of phosphate debris suggest reworking and an environment beyond the sites of most active deposition, such as the inner shelf.

Figure 11. Lithofacies 4, planar-laminated or rippled subarkosic arenite or feldspathic wacke; all samples except thin section $\mathrm{J}$ are from measured section 1 on Discovery Ridge. $A$, Thin section $J$ (table 2) of feldspathic wacke (from measured section 7) in which plagioclase is more abundant than potassium feldspar; crossed polarizers. $B$, Hand specimen of interferencerippled subarkosic arenite containing disseminated muscovite. $C$, Thin section $\mathrm{G}$ (table 2) of subarkosic arenite; crossed polarizers. $D$, Hand specimen of planarlaminated subarkosic arenite. $E$, Thin section $E$ (table 2) of specimen shown in figure 11D; a heavy-mineral layer (HML) is shown in the top third of the photomicrograph; crossed polarizers. $F$, Contact between lithofacies 3 and 4; hammer handle is about $25 \mathrm{~cm}$ long. Symbols for all thin sections: CAL, cluster of calcite crystals; $\mathrm{K}$, potassium feldspar; M, muscovite; P, plagioclase; $\mathrm{Q}$, quartz; *, matrix of chlorite and muscovite; left-pointing arrow, epidote; downward-pointing arrow, magnetite in chlorite matrix.
Lithofacies 7.-In section 1, lithofacies 7 ranges from a fine-grained, subarkosic arenite, rich in the disarticulated shells of the pelecypods Nuculites and Nuculoidea and the gastropod Plectonotus, to a fine-grained, quartzose limestone containing abundant Tentaculites (figs. 5, $12 A, B ;$ Tentaculites is a narrow, annulated cone as long as $1.5 \mathrm{~cm}$, probably a worm tube according to Ellis Yochelson, USGS, written commun., 1983). The limestone contains 69 percent calcite matrix, 10 percent quartz, less than 5 percent each of muscovite and other minerals, and no feldspar (figs. $12 A, B$; table 2, thin section $\mathrm{H}$ ). The calcite matrix may be partly small shell fragments but is mostly of secondary origin. Pelecypod and brachiopod fragments make up 15 percent of the rock, and chalcedony has replaced the calcite in some of them. This lithofacies is generally dark brown and easily seen although the units are less than $1 \mathrm{~m}$ thick, are typically thinner than $20 \mathrm{~cm}$, and compose less than 1 percent of section 1 . The abundance of carbonate reflects an environment seaward of active clastic deposition, probably on the inner shelf.
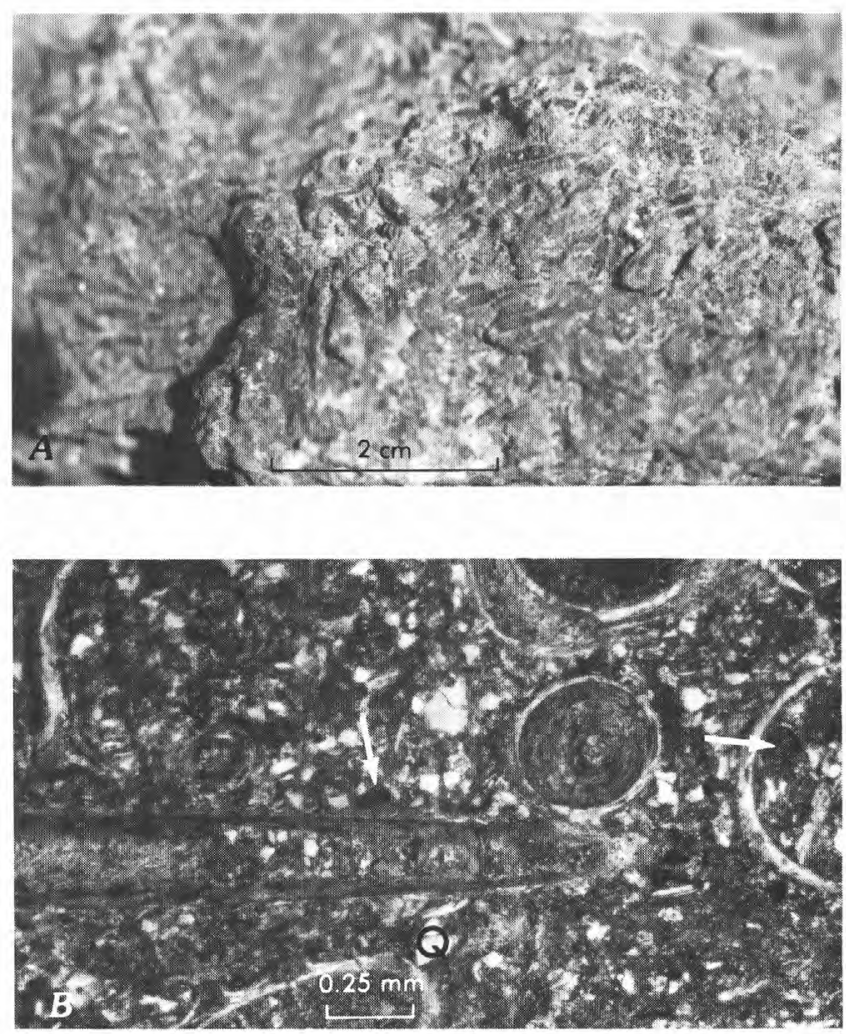

Figure 12. A sample of lithofacies 7, Tentaculites-rich quartzose limestone from measured section 1 on Discovery Ridge. $A$, Hand specimen. $B$, Thin section $\mathrm{H}$ (table 2) of specimen shown in figure $12 A$; plane light. Most of the light, subangular grains are quartz (Q); heavy minerals include magnetite (downward-pointing arrow) and epidote (right-pointing arrow). Many longitudinal and transverse sections through partially silicified Tentaculites shells occur within the calcite matrix. 
Lithofacies 8.-Lithofacies 8 , found only at the top of sections 1 and 2, grades downward from medium- to coarse-grained, silica-cemented subarkosic arenite to feldspathic wacke having a chlorite matrix (figs. 5, 13A, $B$, 14; table 2, thin section I). It is characterized by the brachiopod Australospirifer, echinoid fragments, funnelshaped burrows filled with lithified mud (Rosselia), and rings as much as $10 \mathrm{~cm}$ across of coarse sand grains segregated by biologic activity. Lithofacies 8 makes up about 3 percent of section 1 and was probably deposited in the steeper parts of subtidal bars. Apparently lithofacies 8 was eroded from the tops of other sections prior to deposition of Carboniferous and Permian glacial deposits.

\section{Sections 2 and 3, Discovery Ridge}

Sections 2 (50 m thick) and 3 (44 m thick) were measured on Discovery Ridge (figs. 1, 2, 6). Section 2, on the east side of the west spur of Discovery Ridge, is very
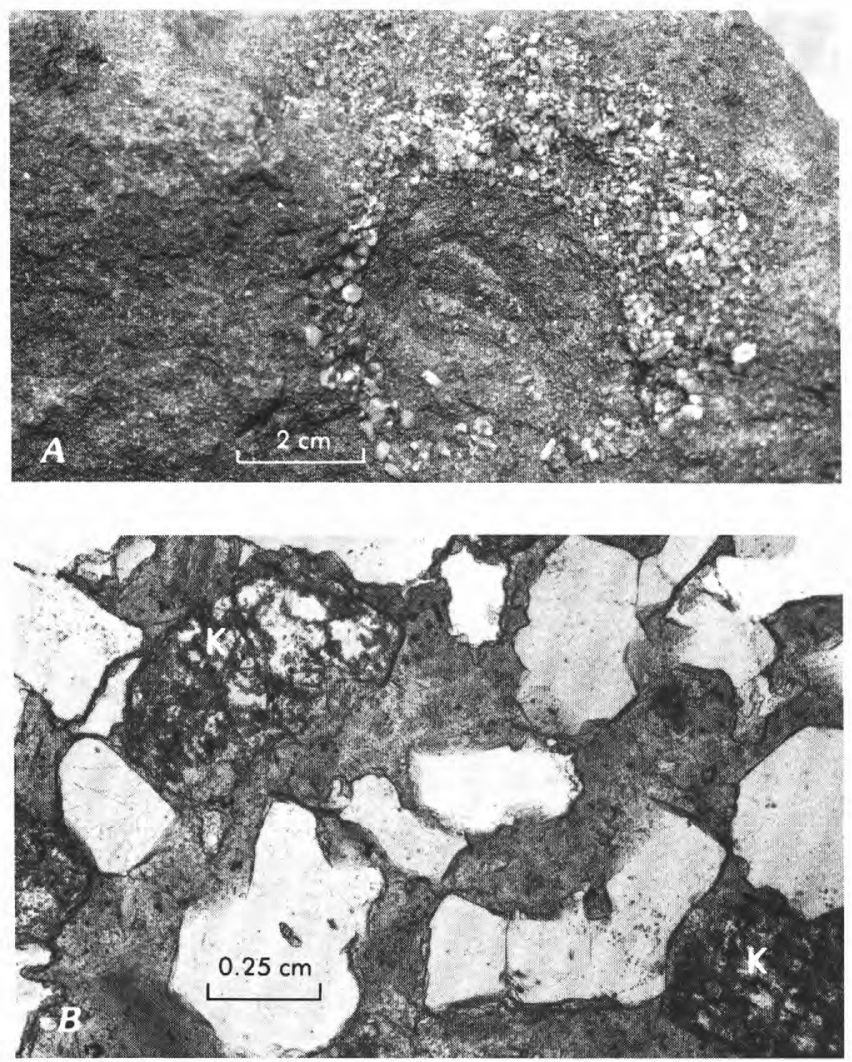

Figure 13. A sample of lithofacies 8 , fossiliferous feldspathic wacke, from the top of measured section 1 on Discovery Ridge. $A$, Hand specimen from the lower side of an overhang. Note a ring-shaped feature, caused by biologic segregation of coarse quartz and feldspar grains in a large burrow; the segregation continues upward (into the page) as a vertical cylinder for several centimeters. $B$, Thin section I (table 2) of specimen shown in figure 13A; plane light. The matrix is chlorite; potassium feldspar $(K)$ is present; light-colored patches are quartz grains having irregular surfaces due to epitaxial growth. similar to section 1 and is slightly thicker. Section 2 contains less shale and more pebbly sandstone than does section 1 (figs. 4, 6). Section 3, poorly exposed on the west side of the west spur, has somewhat more shale than does section 2. Lithofacies 8 is missing from the top of section 3 .

\section{Sections 4-6, Central Ohio Range}

Sections 4,5 , and 6 were measured in the central part of the Ohio Range (figs. 1, 15). On Otago Spur, the first spur west of Discovery Ridge, Carboniferous and Permian glacial deposits rest directly on basement. Section 4 , on the second spur west of Discovery Ridge, is $29 \mathrm{~m}$ thick. It is more than 90 percent medium- to coarsegrained subarkosic arenite and a few percent dark fossiliferous mudstone. Most of the sandstone is crossbedded. The more massive sandstone has scattered body fossils and is bioturbated. A thin bed of arenaceous conglomerate at the base of the section contains subangular clasts of quartz and feldspar as long as $8 \mathrm{~cm}$. Several meters above the base is a fossiliferous bed in which Nuculites is dominant and bellerophontids, tentaculitids, and modiomorphids are also present.

Section 5, on the east spur of Schulthess Buttress, is $21 \mathrm{~m}$ thick. Although poorly exposed, this section reveals several lithofacies, mainly alternations of lithofacies 2,3 , and 4, and is therefore more like the Discovery Ridge sections than it is like sections 4 and 6 . At the top of section 5 is $3 \mathrm{~m}$ of crossbedded, coarse-grained, subarkosic arenite containing crossbed sets about $15 \mathrm{~cm}$ thick (lithofacies 5). The channeled sequence of sandstone shown at the top of this section by Long (1965, fig. 7) is part of the overlying Buckeye Tillite, and the Horlick Formation is thinner than Long recorded.

Section 6, on the west spur of Schulthess Buttress, is $10 \mathrm{~m}$ thick. This section is composed almost entirely of arkosic arenite containing angular to subrounded pebbles

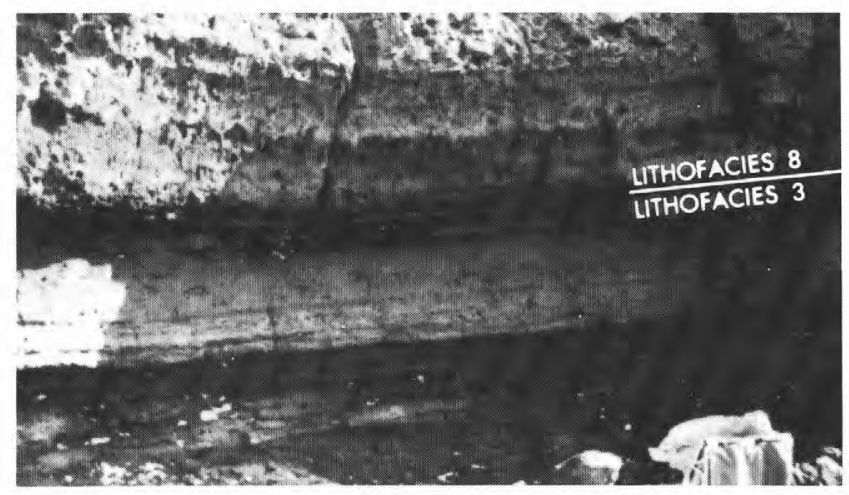

Figure 14. Top of Horlick Formation in measured section 2 on Discovery Ridge. Lithofacies 8 , which contains abundant spiriferids and other shells and Rosselia and other burrows, grades down into the interbedded sandstone and shale of lithofacies 3 . Pack is about $0.4 \mathrm{~m}$ across. 


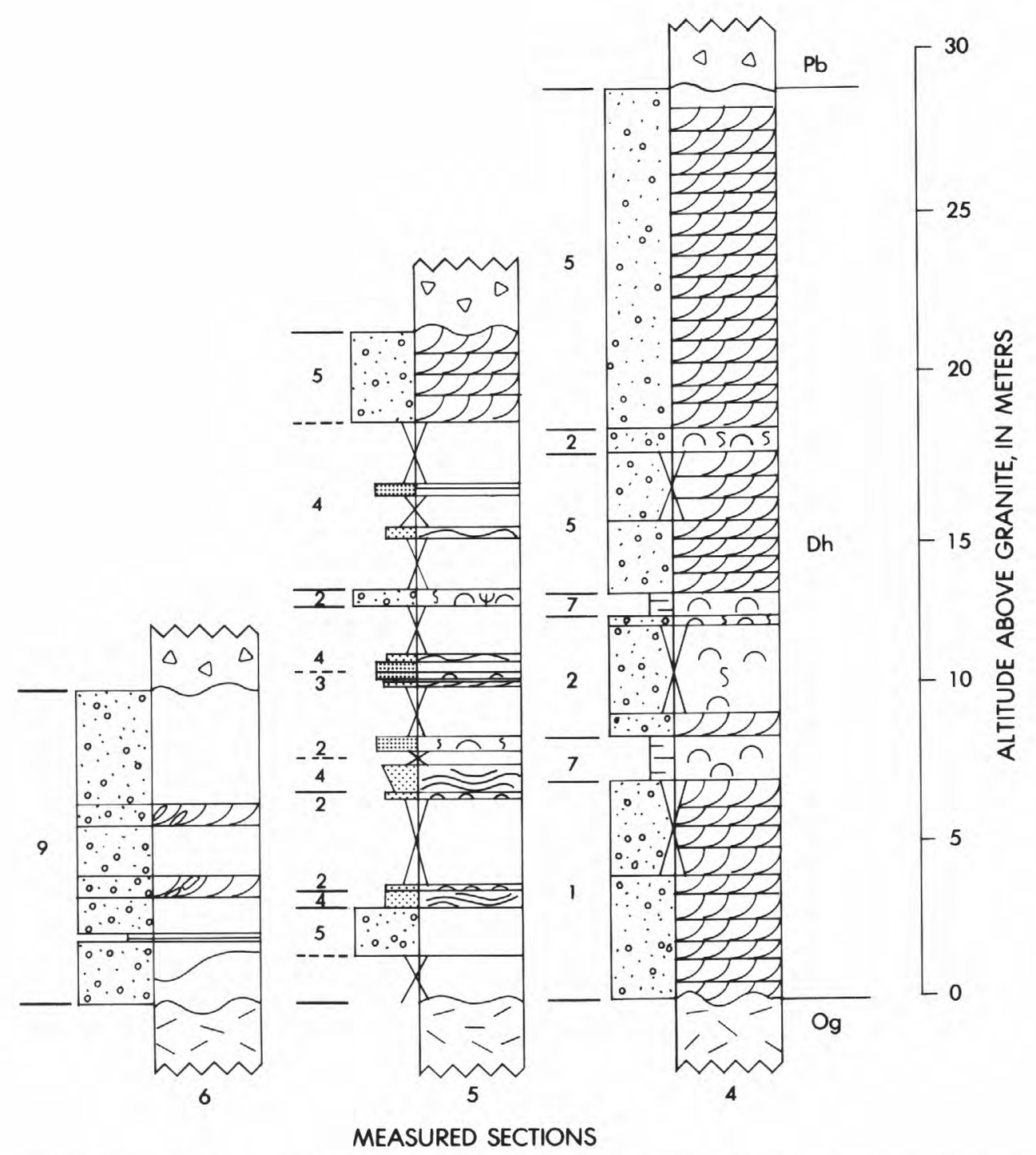

Figure 15. Measured sections 4-6, central Ohio Range. Texture and structure symbols are explained in figure 5. Pb, Buckeye Tillite; Dh, Horlick Formation; Og, Ordovician granite.

and not containing fossils (lithofacies 9, table 1). The basal bed contains angular clasts of quartz and feldspar as long as $6 \mathrm{~cm}$, and coarse-grained layers are repeated higher in the section. A single thin shale bed is present $2 \mathrm{~m}$ above the base of the section, and large shale clasts are present elsewhere in the section. Unique in this section are climbing backflow ripples. The dip of the upper surface of each set of cross laminations indicates the true current direction, toward the east and southeast, but individual foresets within the set dip upstream, toward the west and northwest. This is the only lithofacies without body or trace fossils. The texture, backflow ripples, and lack of fossils suggest fluvial deposition.

\section{Sections 7, 8, 9A, 9B, 10A, and 10B, Darling Ridge}

The Darling Ridge sections (figs. 1, 16) are generally finer grained than sections farther east (fig. 4). Section
7 , measured on a spur on the east side of Darling Ridge, is $18 \mathrm{~m}$ thick. The lower half is medium- to coarse-grained subarkosic arenite, and the upper half is mainly shale and fine-grained sandstone. In one place, the fine-grained sandstone is a calcareous wacke that is $\mathbf{3 1}$ percent calcite and 7 percent chlorite (table 2, thin section $\mathrm{K}$ ). About $11 \mathrm{~m}$ above the base are $10-\mathrm{cm}$-thick beds of shale separated by three thin sandstone beds that contain phosphatized pebbles and bone fragments. Just above is a thin bed of lithofacies 4 (not shown in fig. 16), which contains 26 percent chlorite matrix and in which plagioclase is more abundant than potassium feldspar (table 2, thin section $\mathrm{J}$ ).

Section 8, from the east spur on the northern end of Darling Ridge, is $29 \mathrm{~m}$ thick. It is mainly fine- to medium-grained subarkosic arenite and shale, but slightly coarser beds are present at the base. Quartz clasts as large 


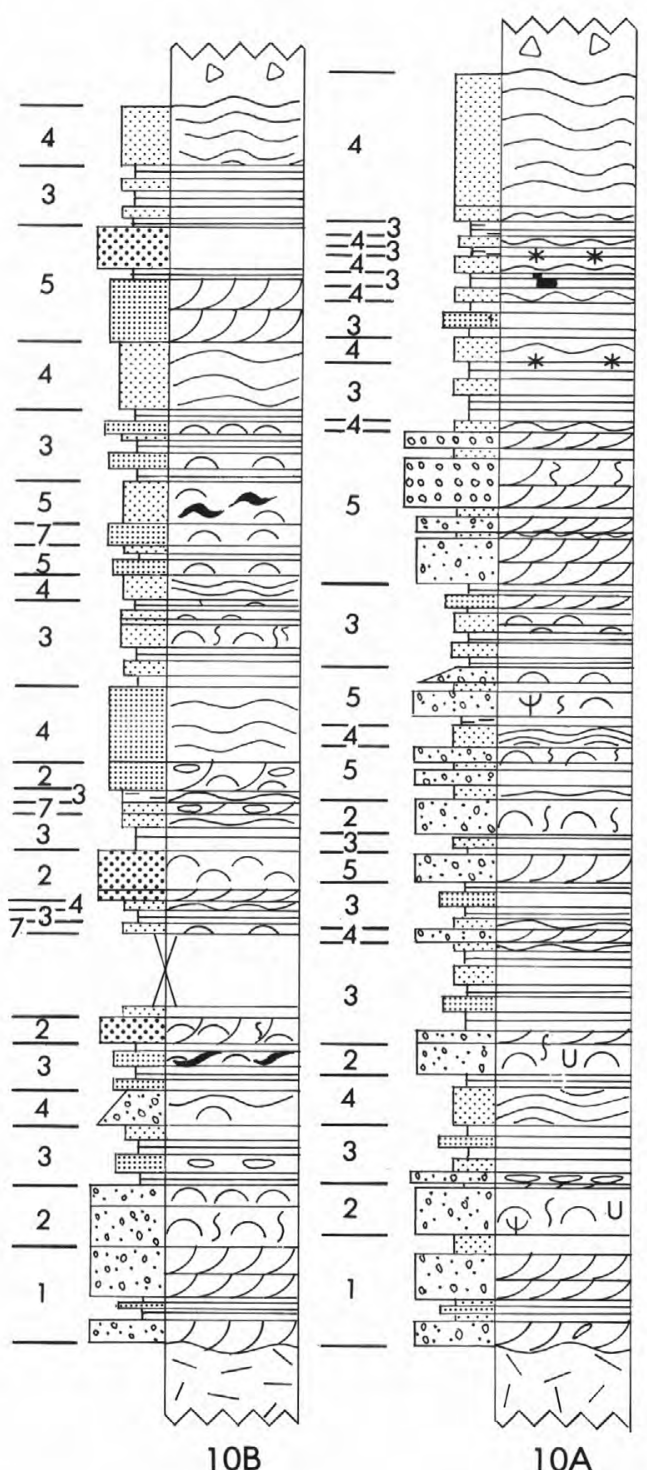

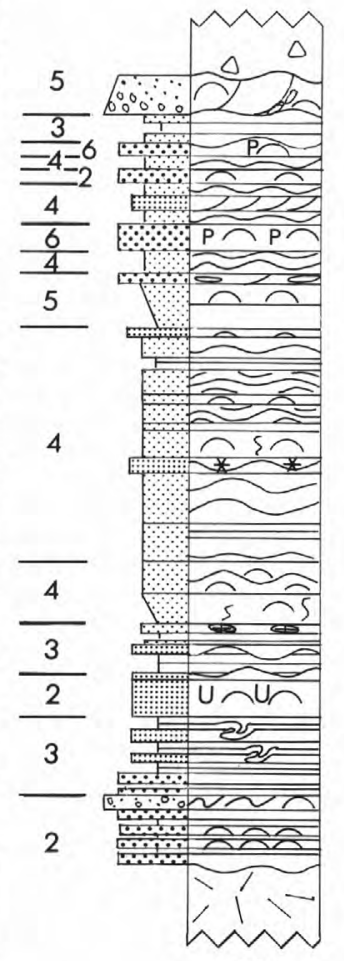

9B

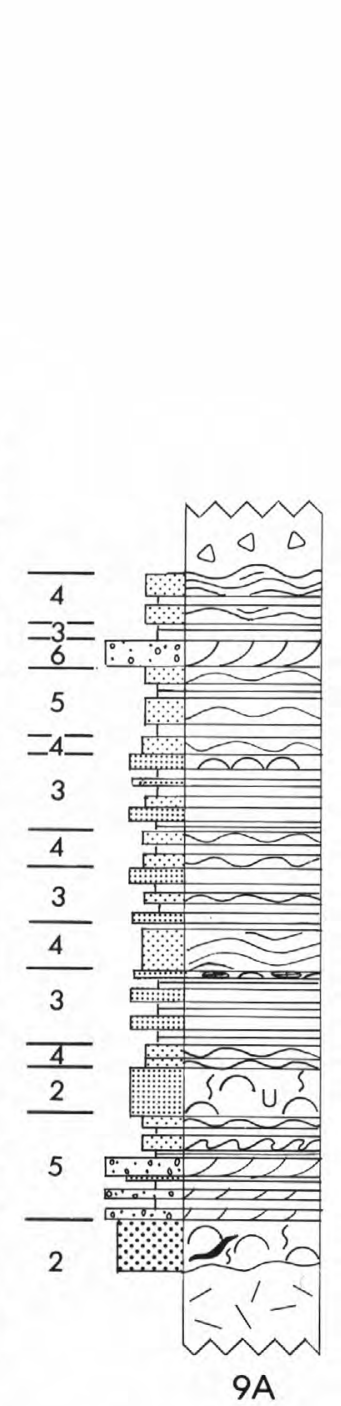

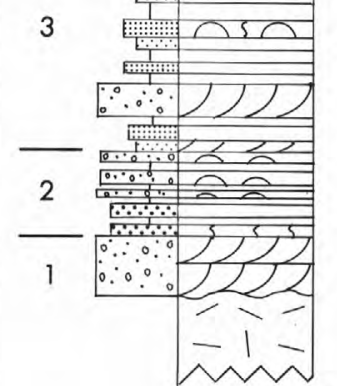

8

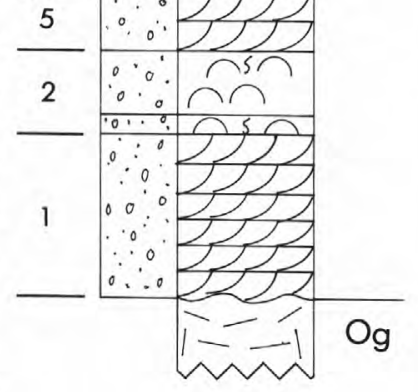

7

MEASURED SECTIONS

Figure 16. Measured sections 7, 8, 9A, 9B, 10A, and 10B, Darling Ridge. Texture and structure symbols are explained in figure 5. Pb, Buckeye Tillite; Dh, Horlick Formation; Og, Ordovician granite. 
as $13 \mathrm{~cm}$ are present at the basal contact. Lithofacies 2 , above the $1.5 \mathrm{~m}$ of lithofacies 1 at the base, contains several beds of bioturbated subarkosic sandstone interbedded with thin shale. Pleurothyrella is common in the upper three beds. The remainder of the section is predominantly lithofacies 3 and 4. A single example of lithofacies 6 was observed at $10 \mathrm{~m}$ above the granite. At about $15 \mathrm{~m}$ above the base, $2.2 \mathrm{~m}$ of lithofacies 3 grades up into a bed of lithofacies 4 having horizontal trace fossils on its upper surface. A thin, fine-grained sandstone, unusually rich in homalonotid trilobite material, Plectonotus, and less common Prothyris, Paleosolen, and Nuculites, occurs at about $17.5 \mathrm{~m}$. At $20 \mathrm{~m}$, a 1.5 -m-thick, upward-fining unit of lithofacies 5 is ripple laminated at the top. The remainder of the section is mainly lithofacies 3 and 4 , containing lineations in the planar sandstones. At the top of the section, fine-grained sandstone of the Horlick Formation is brecciated for $50 \mathrm{~cm}$ immediately below the overlying Buckeye Tillite.

Sections 9A and 9B, measured on the west spur of the northern end of Darling Ridge, are about 18 and $20 \mathrm{~m}$ thick, respectively. They resemble section 8 in becoming finer grained upward. These sections are unique in that lithofacies 1 is absent, and lithofacies 2 rests directly on basement. Contorted bedding, apparently due to softsediment deformation, occurs about $3 \mathrm{~m}$ above the base in section 9B, in lithofacies 3 . At about $3.5 \mathrm{~m}$ above the base in both sections is a bed of lithofacies 2 containing articulated Modiomorpha and Pleurothyrella, some of which may be in life position, and also U-shaped burrows lined with lithified silt. Higher sandstones are generally fine to medium grained and have many ripple laminations. About $10 \mathrm{~m}$ above the base in section 9B, arthropod walking tracks are present in the bedding planes of medium-grained sandstone. Fossils tend to be concentrated as disarticulated shells in thin (about 20-cm-thick), coarse, sandstone beds, probably storm deposits. The crossbedded sandstones of lithofacies 6 are interbedded with finer grained rocks of lithofacies 3 and 4 near the tops of the sections and also appear to pass laterally into them. One meter of coarse-grained sandstone of lithofacies 5 occurs at the top of section 9B, but in section 9A, the corresponding position is occupied by a channel containing Buckeye Tillite.

Sections $10 \mathrm{~A}$ and $10 \mathrm{~B}$, from a spur on the west side of Darling Ridge, are both about $31 \mathrm{~m}$ thick. The basal unit, lithofacies 1 , has more beds in sections $10 \mathrm{~A}$ and $10 \mathrm{~B}$ than elsewhere in the Ohio Range. Thin shales separating some of the sandstone beds contain numerous horizontal burrows. Also, near the base of the sections is a $13-\mathrm{cm}-$ thick bed of hard, brown-weathering quartz arenite that contains small vertical burrows. About $1.5 \mathrm{~m}$ of lithofacies 2 containing scattered Pleurothyrella overlies the basal unit. Most of the Horlick at these localities is made up of lithofacies 2,3,4, and 5. Trilobite fragments and trackways are abundant in some beds, particularly near the top of section $10 \mathrm{~A}$. About 10,13, and $18 \mathrm{~m}$ above the base of section $10 \mathrm{~B}$, lithofacies 7 is present. The bed at $10 \mathrm{~m}$ contains an unusual mixture of Nuculites, Modiomorpha, Pleurothyrella, and trilobite fragments, with rare Orbiculoidea. In the bed at $18 \mathrm{~m}$, Nuculites are predominant in the lower part, and Tentaculites, in the upper part. A few Pleurothyrella, Modiomorpha, and Paleosolen are also present. A few Tentaculites were also observed at about $12 \mathrm{~m}$ above the base within lithofacies 3 .

\section{Sections 11-15, Lackey Ridge}

Sections 11-15 were measured on Lackey Ridge (figs. 1, 3, 4, 17). Section 11, in Echo Canyon, is $21 \mathrm{~m}$ thick and is mainly fine-grained subarkosic arenite and shale. A fragmented valve of Orbiculoidea was found at the basal contact, confirming the marine origin of lithofacies 1 . The succeeding lithofacies 2 is thinly bedded and contains U-shaped burrows lined with lithified mud. Vertical burrows are also present. Four beds of lithofacies 7 are present between 5 and $10 \mathrm{~m}$ above the base. Lithofacies 2 makes up a larger proportion of section 11 than it does of most other sections.

Section 12, on Thumb Promontory, is $24 \mathrm{~m}$ thick. It is similar to Discovery Ridge sections in distribution of textures but also contains many trilobite fragments and traces like those at Darling Ridge. The basal $2 \mathrm{~m}$ is composed of coarse- to medium-grained sandstone containing thin shale layers. This sandstone contains rare Pleurothyrella fragments, reworked phosphatic nodules, bones, and large-scale ripples; the shale contains psilophyte plant fragments. At about $6 \mathrm{~m}$ above the base, a conspicuous bed of lithofacies 7 grades laterally into slightly fossiliferous mudstone. Just above, lithofacies 6 contains Lingula, fish plates, fish bones, reworked phosphatic nodules, trilobite debris, and broken Pleurothyrella shells. It is interbedded with lithofacies 5. Near the top of section 12 , a bed of lithofacies 4 contains trilobite traces.

The remaining Lackey Ridge sections are $14 \mathrm{~m}$ or less and contain more sandstone than most of the sections described above. At the westernmost point on the ridge, only $2 \mathrm{~m}$ of Horlick Formation is present (fig. 2; no section shown). The lowermost $80 \mathrm{~cm}$ is lithofacies 1 , and the remainder is lithofacies 2 .

Section 13 is $14 \mathrm{~m}$ thick, and the basal $1.5 \mathrm{~m}$ is poorly exposed. Lithofacies 5 fills channels in lithofacies 2 and 3 at about $2 \mathrm{~m}$ above the base. The lower part of the lithofacies 5 bed is trough crossbedded and contains pebble layers and rare brachiopod shells. It grades up into lithofacies 4 at about $5 \mathrm{~m}$. On planar bedding planes of lithofacies 4 are arthropod trackways and small burrow exit holes. The planar bedding planes reflect fairly high energy (storm waves), and the trackways were produced 


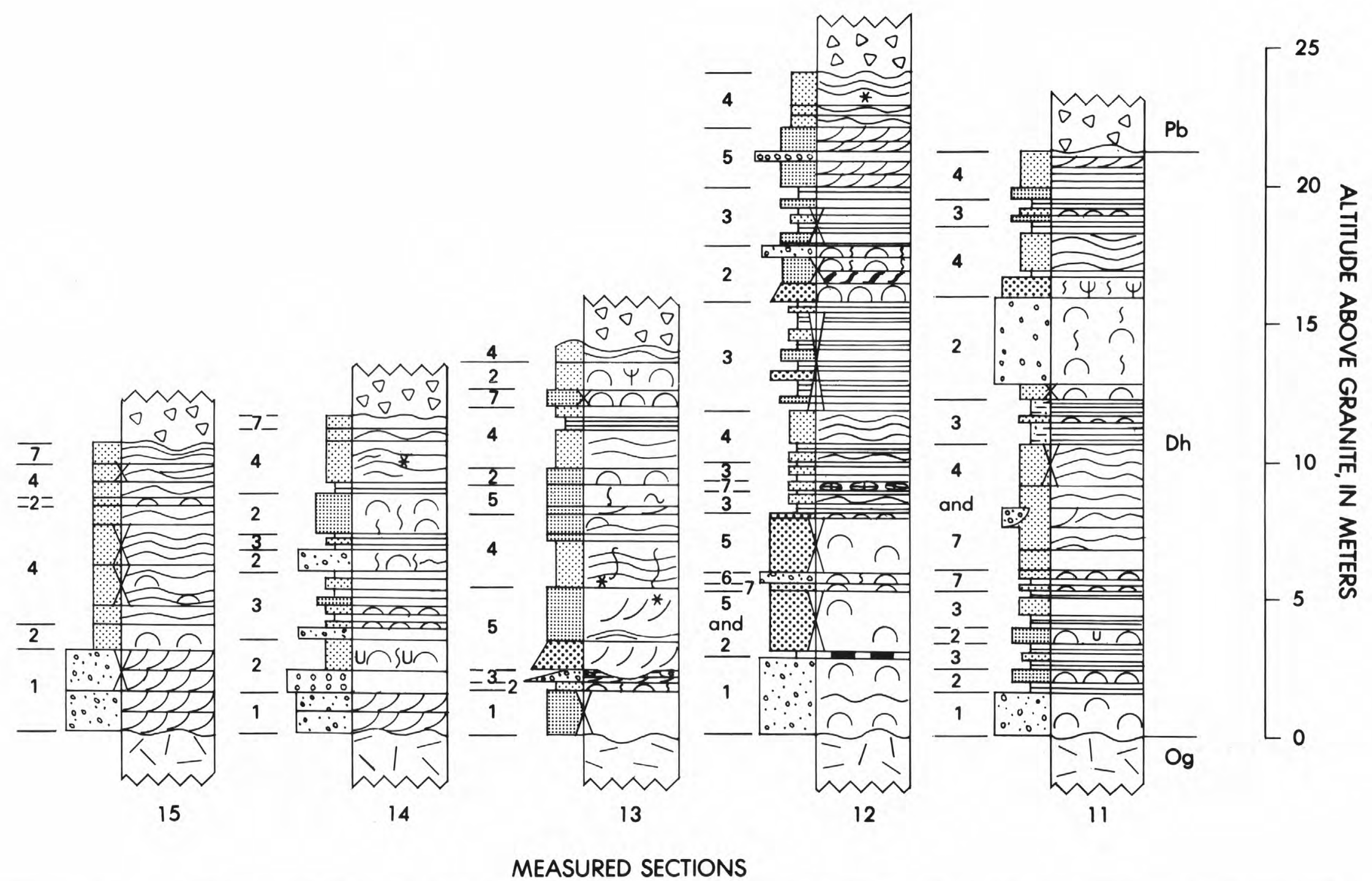

Figure 17. Measured sections 11-15, Lackey Ridge. Texture and structure symbols are explained in figure 5. Pb, Buckeye Tillite; Dh, Horlick Formation; Og, Ordovician granite. 
during quiet periods. Between about 8 and $9 \mathrm{~m}$, lithofacies 2 beds contain Paleosolen, Pleurothyrella, and Modiomorpha. At about $11.5 \mathrm{~m}$, beds contain Tentaculites, Pleurothyrella, and Nuculites. At the top of the section, Rosselia burrows and Pleurothyrella occur in fine- to medium-grained, poorly sorted sandstone.

Section 14, at Trilobite Promenade, is $12 \mathrm{~m}$ thick. Immediately to the west, the Buckeye Tillite rests directly on basement. Lithofacies 1 occupies the basal $1.5 \mathrm{~m}$ of the section and is followed by alternations of lithofacies 2,3 , and 4. Many of the lithofacies 2 beds are burrowed in the lower part and have concentrations of shell fragments above. At $10 \mathrm{~m}$, a thick unit of lithofacies 4 has abundant Cruziana and Rusophycus, walking and resting traces of trilobites. At the top of the section is lithofacies 7 .

In section $15,10.5 \mathrm{~m}$ of sediment has been preserved, but exposure is poor. However, lithofacies 1, 2, and 4 are definitely present. At the top of the section is a bed of lithofacies 7 that is very rich in Nuculites and Tentaculites, that has fewer bellerophontids and other shells, and that might correlate with the top of section 14 .

\section{Petrology and Mineralogy}

Granitic source rocks.-With the exception of some of the chlorite, most clasts in the Horlick Formation appear to be either intraformational (lithified mud chips and fossils) or derived from the granitic rocks that underlie it. Treves (1965), in a thorough examination of the basement rocks, concluded that pink quartz monzonite intruded gray granodiorite. The granite at the base of Discovery Ridge (figs. $18 A, B$; table 2 , thin section $\mathrm{A}$ ) contains about 44 percent quartz, 20 percent potassium feldspar, 29 percent plagioclase, 6 percent biotite and chlorite, 1 percent diopside, and 1 percent sphene. The plagioclase ranges from andesine $\left(\mathrm{An}_{35}\right)$ to oligoclase $\left(\mathrm{An}_{27}\right)$. Much of the potassium feldspar has an unusual spherulitic texture. The biotite monzogranite at the base of the second spur west of Discovery Ridge (section 4) has roughly equal proportions of quartz, potassium feldspar, and plagioclase-a composition slightly more quartz rich than quartz monzonite but less calcic than granodiorite (table 2, thin section B).

Feldspar.-The detrital mineralogy of sedimentary rocks reflects the mineralogy of the source rocks modified by weathering, abrasion, and dissolution during transportation, deposition, and diagenesis. In general, more abrasion, and thus removal, of feldspars and less resistant heavy minerals occurs in the surf zone than elsewhere in the intertidal and shallow subtidal environment. Heavy minerals, however, tend to be concentrated on beaches by normal wave action and, less commonly, offshore by storm waves.

The lithology characterized by interference ripples (lithofacies 4) has the highest proportion of plagioclase to potassium feldspar in the Horlick Formation. The granitic source also has more plagioclase than potassium feldspar. This feldspar distribution suggests that more fresh material accumulated in this lithofacies than in other Horlick Formation lithofacies.

The sandstone at the base of the Horlick Formation (lithofacies 1) and the Tentaculites beds (lithofacies 7) contain little feldspar at most localities. The basal sandstone is quartz rich in many places and contains less than 5 percent feldspar, probably because the feldspar had weathered out of the granite regolith that was the source material for the basal beds of the Horlick Formation. After the regolith was eroded, only fresher detritus was available, as reflected in the subarkosic nature of the rest of the Horlick's sandstone.

Limestone.-The Tentaculites beds (lithofacies 7) consist of fine-grained subarkosic arenite and quartzose limestone; they contain the finest grained sandstone and the highest proportions of biogenic and secondary calcite in the Horlick Formation. The fossils-predominantly Tentaculites and Nuculites, with fewer bellerophontids and other shells-together with the fineness of the sandstone and abundance of calcite, suggest that the environment of
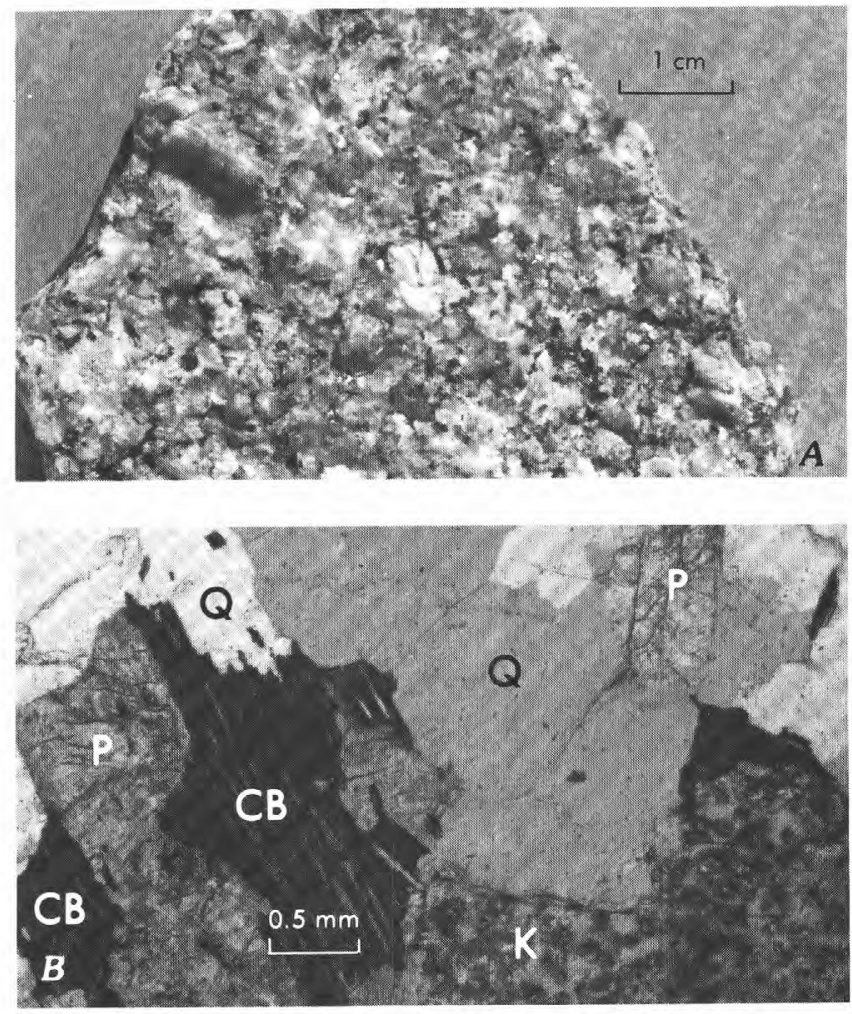

Figure 18. A sample of the granite underlying the Horlick Formation. Most Horlick sediment was derived from this hypidiomorphic, inequigranular granite. $A$, Hand specimen from base of Discovery Ridge, measured section 1. $B$, Thin section $A$ (table 2) from hand specimen shown in figure $18 A$; plane light. $\mathrm{CB}$, chloritized biotite; $\mathrm{K}$, potassium feldspar having an unusual exsolution texture; $P$, plagioclase; Q, quartz. 
deposition for this lithofacies was deeper or farther from shore than environments for other lithofacies. The paucity of feldspar in this lithofacies is most likely due to its having been thoroughly abraded in the shallower environments, leaving only fine quartz particles to move into the calcareous sands accumulating slowly offshore.

Diagenetic minerals.-Several lithologic changes have taken place since deposition of the Horlick Formation. For example, most of the angularity of sand grains is due to diagenetic processes: (1) pressure solution at grain-to-grain contact points, (2) infilling of pressure shadows by secondary quartz, and (3) formation of irregular growth rims, mainly of quartz. Original grain shapes are obscured; they were probably mostly subrounded, as indicated by energy of the depositional environment inferred from the accompanying sedimentary structures.

Secondary chlorite (long or patchy crystals; see Pettijohn and others, 1973, Dott, 1964, and Hawkins and Whetten, 1969, for discussion of secondary minerals) and partly to completely recrystallized calcite matrix are present in sandstones at several places throughout the Horlick Formation. Hower and others (1976) found that diagenetic chlorite is not an appreciable phase in argillaceous sediment that has been buried less than about 2,200 $\mathrm{m}$ on the U.S. Gulf of Mexico Coast, and calcite content drops to less than 15 percent at burial depths below $2,500 \mathrm{~m}$. The presence of both calcite and chlorite in large proportions in the Horlick Formation, therefore, may suggest an overburden of about $2,500 \mathrm{~m}$ at some time since the Devonian. The present overburden of Carboniferous and Permian glacial and lake deposits, capped in places by a Jurassic diabase sill, is about $900 \mathrm{~m}$ thick. Thus, as much as $1,650 \mathrm{~m}$ of post-Horlick sediment may have been eroded.

\section{DEPOSITIONAL ENVIRONMENTS OF THE HORLICK FORMATION}

Conditions under which the Horlick Formation was deposited can be inferred from the distribution of textures, fossils, minerals, and sedimentary structures that indicate current directions.

\section{Current-Direction Indicators}

Orientations of channels, crossbeds, ripples, planar beds, and current lineations and the general direction of accretion of crossbed sets (direction of axial dip in trough crossbeds) were plotted for 14 sections measured at 12 localities (figs. 19-21). All data are recorded in linear (true dip, plunge, trend) rather than planar (strike and dip) notation in order to facilitate comparison. For example, $\mathrm{C} 10 \rightarrow 295^{\circ}$ is a channel whose axis plunges $10^{\circ}$ toward $295^{\circ}$, and $\mathrm{X} 17 \rightarrow \mathrm{S}$ is a crossbed that dips $17^{\circ}$ toward the south and strikes approximately east-west. $\mathrm{X} 24 \rightarrow 275^{\circ}$ is a crossbed that dips $24^{\circ}$ toward $275^{\circ}$ and has a strike of $185^{\circ}$. Other symbols are defined in the caption for figure 20. Points of the compass such as NNE are within $20^{\circ}$ of the true directions, and azimuth readings such as $270^{\circ}$ are within about $5^{\circ}$ of the true direction. All original compass readings were magnetic and have been converted to geographic directions by adding $75^{\circ}$. True geographic north was determined in the field with a sun compass by Karl Kellogg, USGS.

Current-direction indicators are shown graphically in three ways. In figure 19, the orientation of a structure is shown in map view at the correct height next to a diagram of the appropriate measured section. The angle of dip is given numerically for some structures. Figure 20 lists the orientation of each structure at its approximate level in a diagram of its measured section.

In order to assess vertical changes in attitudes of structures, we divided the measured sections into $10-\mathrm{m}$ intervals (figs. 20,21). Within each interval in figure 21, the indicated current directions are shown in a single cluster so they can be compared with each other. For example, in the lowest $10 \mathrm{~m}$ of section 14 , the planar beds' true dip is toward the south-southeast, accretion is mainly toward the south and southwest, and channel axes trend mainly northeast and southwest.

\section{Direction of Water Movement}

The hypothetical shoreline shown in figure $22 B$ was drawn landward of the known Horlick marine beds and perpendicular to the dip direction of the planar beds associated with sand tongues that we believe were deposited at or above wave base. The dominance of one shore-parallel direction over the opposite direction suggests a wave-generated current during deposition of the Horlick Formation. The westward longshore transport direction was inferred from the current-indicator analysis (fig. 21). In section 1, for example, planar sandstone beds dipping southeastward imply a southwestward-trending shoreline, with land to the northwest. The direction of the onshore component of current movement associated with subtidal megaripples that probably developed on the sides of bars parallel to the shoreline is north to northwest. The southwestward or westward current direction is roughly parallel to the shoreline and perpendicular to the inferred shoreface slope and, therefore, is the longshore transport direction.

Local shoreline directions changed through time because of erosion and deposition, so depositional slope and measurements of similar sedimentary structures at different levels in the Horlick may differ considerably. Current-direction data were recorded in a way that shows the range of directions, rather than the dominant direction. The westward longshore transport direction is dominant in most sections. 
EXPLANATION

Shale, mudstone, siltstone

\section{Fine-grained sandstone}

Medium-grained sandstone

Coarse-grained sandstone, no pebbles

Medium- to coarse-grained sandstone containing pebbles

Fine-grained conglomerate
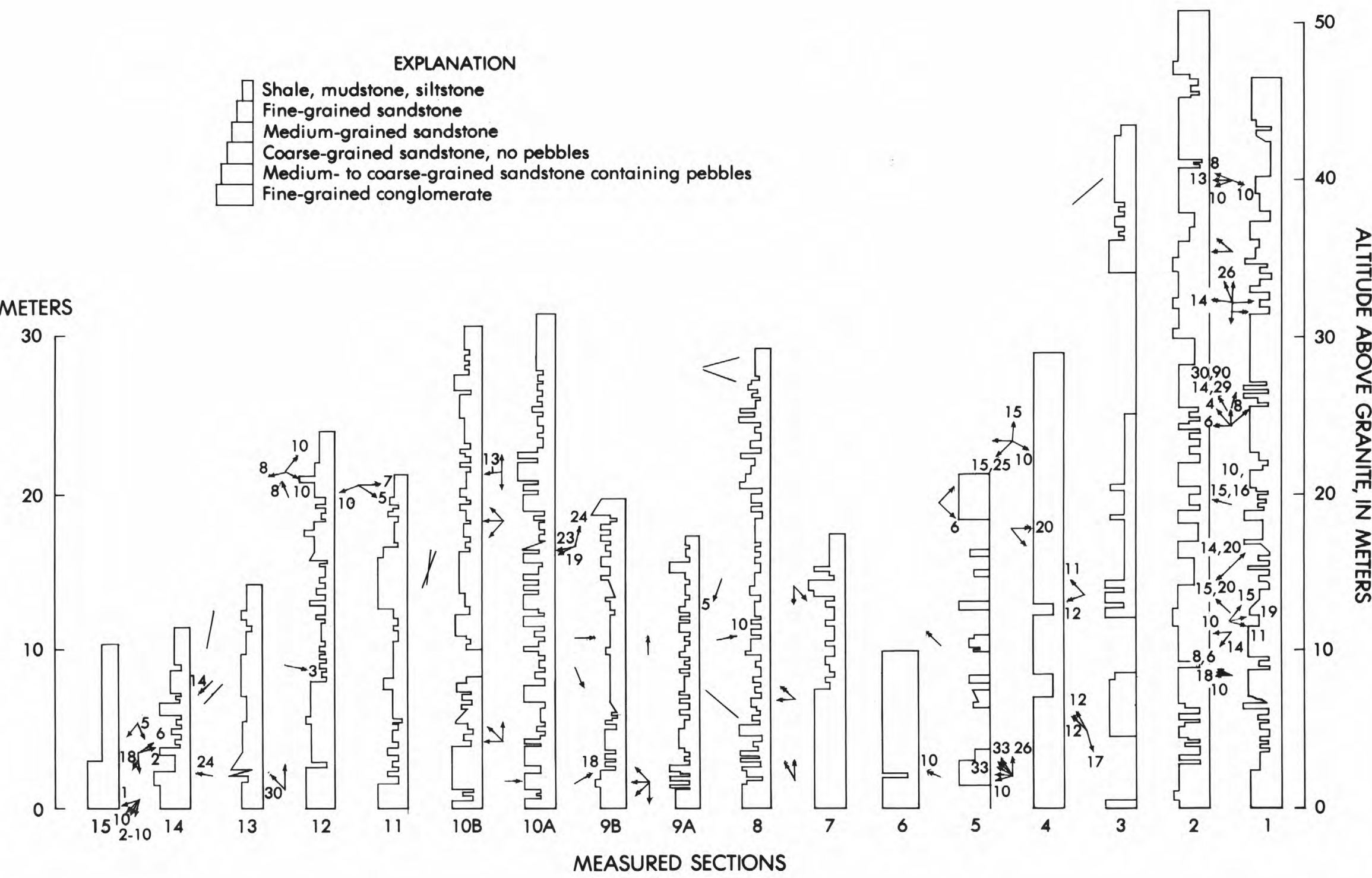

Figure 19. Vertical positions and map-view orientations of current-direction indicators in measured sections through the marine deposits of the Horlick Formation. Texture diagrams of the sections are from figure 4 . The position of a symbol indicates a structure's approximate height above Ordovician granite. Lines and arrows are plotted in normal map orientation; dip and plunge angles are shown

numerically if known. Arrows show directions of channel plunges, planar-bed dips, sediment transport by asymmetric ripples, crossbed dips, and sediment accretion; lines without arrowheads show trends of current lineations and symmetric ripples. No data are available for sections 2 and 15; data from section 6 (not plotted) are discussed in the text. 


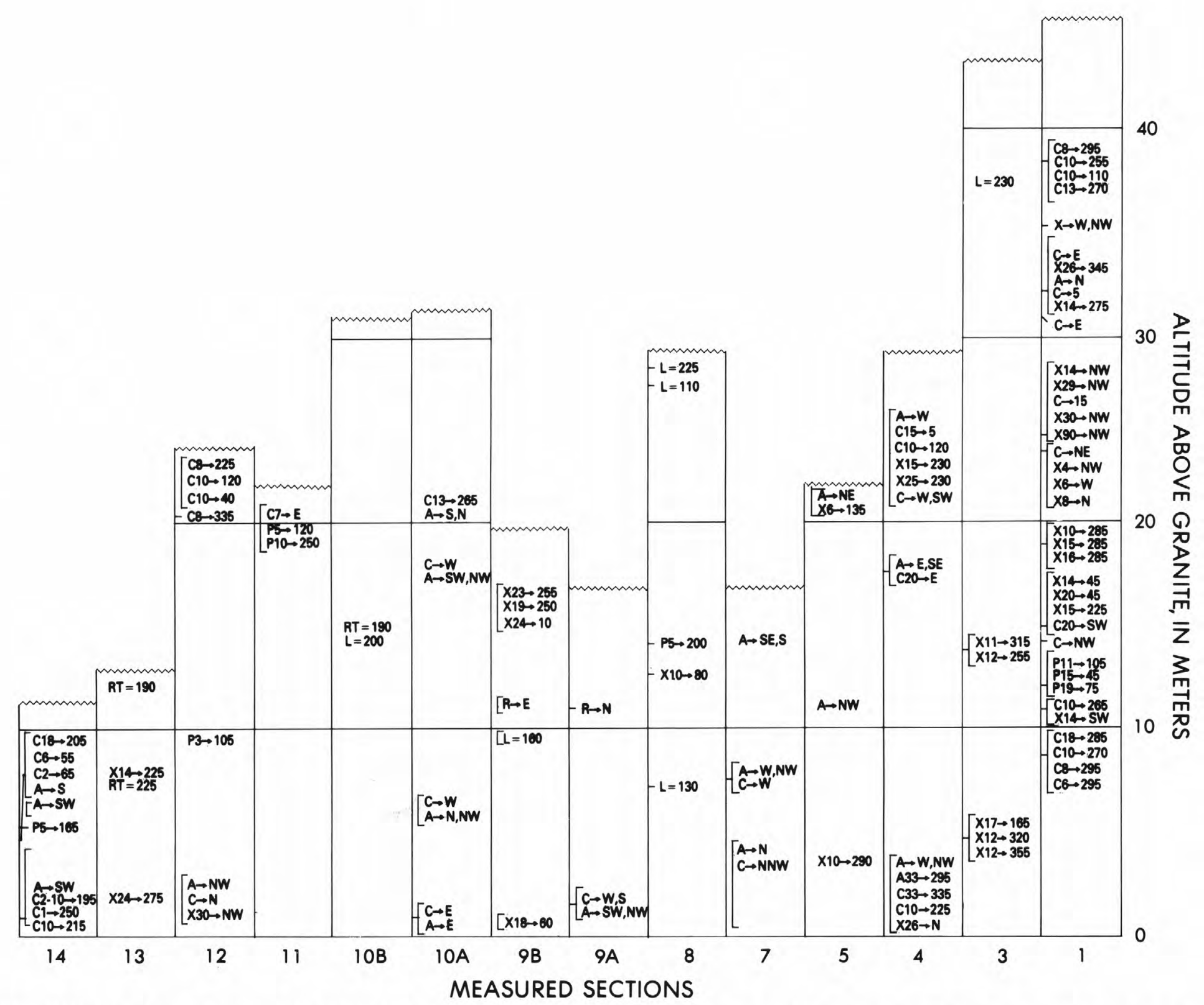

Figure 20. Data from figure 19 expressed in linear notation near the correct level within each measured section. A range of altitudes is given by a bracket without a leader; a specific altitude is given by a leader. Symbols: A, sediment-accretion direction; C, channel-plunge direction; $\mathrm{L}$, current-lineation trend; $\mathrm{P}$, planar-bed dip direction; $\mathrm{R}$, direction of trans port by asymmetric ripple; RT, trend of symmetric ripple crest; $X$, crossbed dip direction. Examples: $C 8 \rightarrow 295$, a channel whose axis plunges $8^{\circ}$ from the horizontal toward $295^{\circ} ; \mathrm{A} \rightarrow \mathrm{W}$, accretion toward true west. 


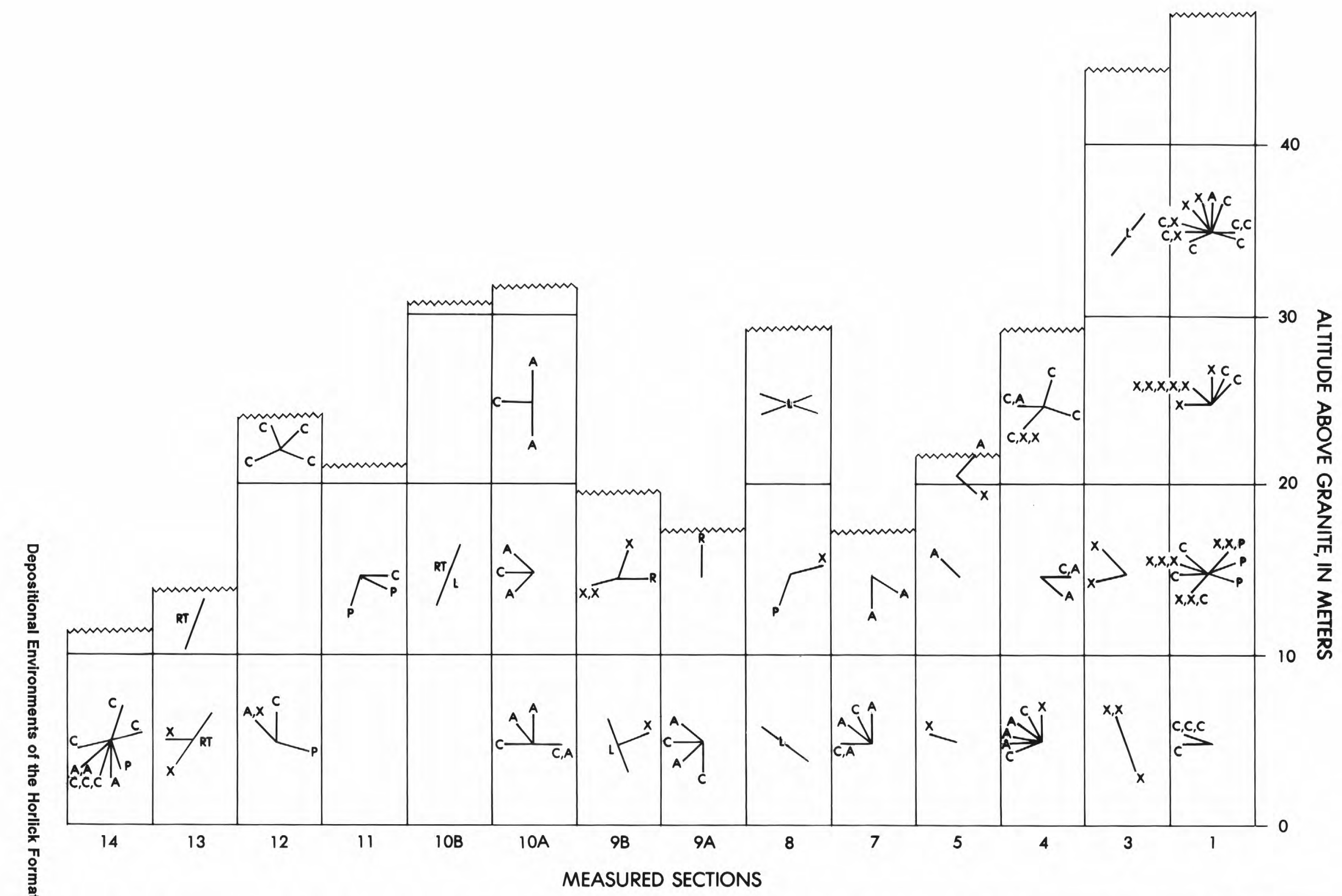

Figure 21. Orientation and type of Horlick Formation current-direction indicators summarized in vertical increments of $10 \mathrm{~m}$ and compass increments of $22.5^{\circ}$. Data and symbols from figures 19 and 20. 


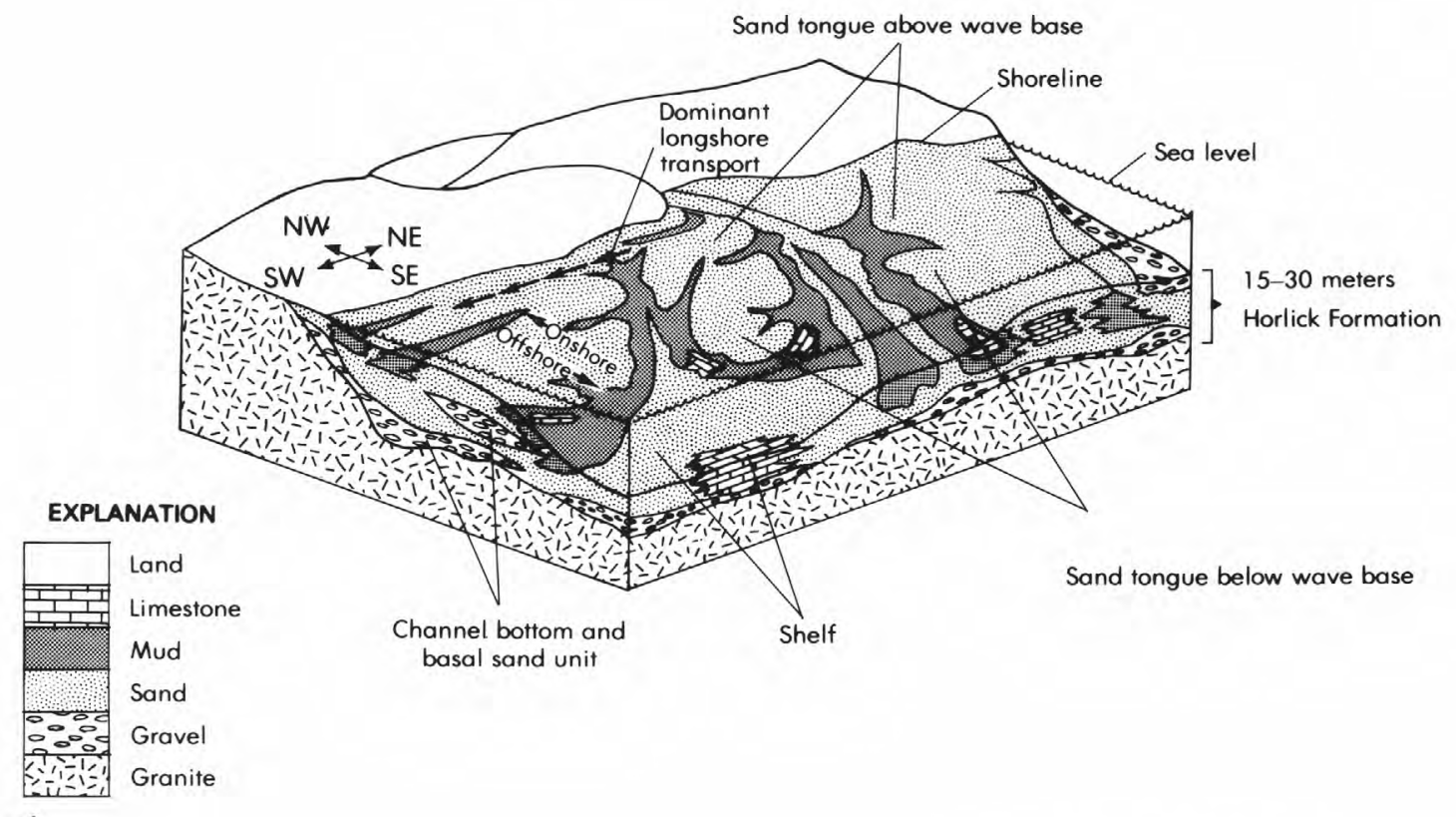

$\boldsymbol{A}$

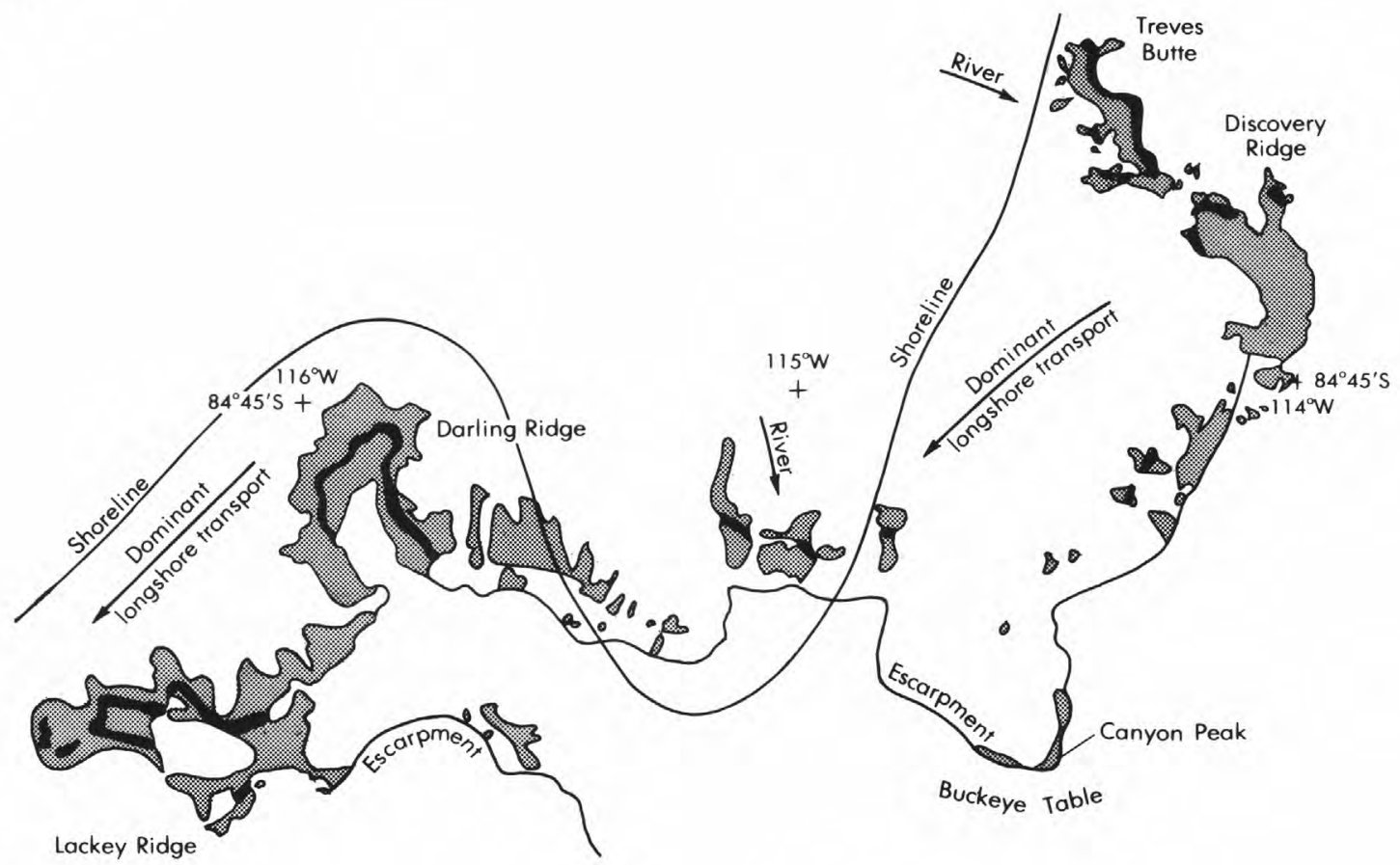

$\boldsymbol{B}$

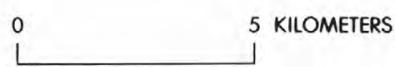

Figure 22. Shoreline position and directions of water movement during deposition of the Horlick Formation. $A$, Idealized block diagram of coastal area in Horlick time, reconstructed from sequences of lithofacies $1-8$ in vertical sections. Environmental conditions in the coastal area were probably similar to those described by Dörjes and others (1970) as existing today in German Bay,

North Sea. We deduce from the stratigraphy that relative sea level was constant. $B$, Map based on figure 2, showing Horlick Formation outcrops (black) and other solid-rock outcrops (gray) and showing a possible position of the shoreline and directions of fluvial influx and longshore transport during part of Horlick time. 


\section{Distribution of Textures and Sedimentary Structures}

The percentage of fine sediment in most Horlick Formation sections indicates that quiet-water environments must have existed for extended periods. The presence of shallow-water marine fossils and assemblages of biogenic and sedimentary structures throughout most of the formation, indicating moderate current activity in several directions, reflects both shallow-water conditions and a balance (or frequent readjustment) between the rate of sediment accumulation and a relative rise in sea level (Curray, 1964). Thin limestone beds suggest low clastic influx in some places, probably offshore. Facies changes that occur within short distances laterally and vertically appear to indicate a complex topographic and hydrographic regime.

Three modern environments in which large proportions of both mud and sand accumulate are the deltas of the northern Gulf of Mexico and the North Sea (Coleman and Gagliano, 1965; Wunderlich, 1970; Reineck and Singh, 1975; see also Reineck and Singh in Dörjes and others, 1970) and barrier-lagoon complexes of the U.S. Atlantic Coastal Plain (McCartan, Lemon, and Weems, 1984; Kraft, 1971). The last example contains an abundance of intertidal organisms, whereas the Horlick fossils appear to be mostly subtidal (for example, homalonotid trilobites and the gastropod Plectonotus in many other Lower Devonian formations have been interpreted as indicating very shallow marine conditions, according to Boucot and others, 1969), but the medium- to coarsegrained, crossbedded sandstone in the Horlick does resemble tidal delta and tidal inlet deposits along the Atlantic.

Because all the structures in the Horlick resemble those in modern environments under less than $10 \mathrm{~m}$ of water (Greenwood and Mittler, 1985), and even the shales of the Horlick are compatible with that depth in a deltaic setting, we infer shallow subtidal conditions for most of the formation. Whether sea level was rising eustatically or the basin was downwarping, the relative rise in sea level was approximately compensated for by sediment introduced by rivers.

Except for barrier-lagoon complexes, wavedominated coasts do not generally appear to provide environments for the accumulation of mud (Greenwood and Davis, 1984). Some of the assemblages of sedimentary structures in the Horlick Formation, however, are very similar to those in the subtidal zone of barred coasts (Greenwood and Mittler, 1985; Hunter and others, 1979).

A reconstruction of the Horlick Formation's environment of deposition must include these characteristics: a low-lying shore having a wave-cut platform; episodic supply of river-transported, plant-bearing sediment voluminous enough to keep pace with the relative rise in sea level; subaqueous topography and water movement giving rise to a dominantly sandy substrate (moderate energy) interspersed with muddy areas that reflect insignificant wave or current activity (low energy); moderate tidal range and wave height and period; and occasional large storms capable of reworking sediment below the normal wave base and of creating large, semipermanent offshore bars.

To account for these characteristics, we suggest as a depositional model a storm-induced bar and trough system modified by waves and by influxes from river-mouth deltas (fig. 22A). As mud and sand reached the sea, they were swept westward by longshore drift. Part of the mud was trapped in troughs that were periodically cut off by sand at their updrift ends; the remainder of the mud blanketed the deeper flanks of sand tongues. Sandstone beds and layers of broken shells within the fine-grained parts of the sequence (lithofacies 3 ) reflect higher energy conditions like those that prevail during storms and spring tides. According to this model, most of the coarse material accumulated as trough-crossbedded sands in active marine channels and in tidal deltas at the river mouths (some of lithofacies 5); in the Horlick Formation basal beds, prior to the creation of the bars (lithofacies 1); and along the steeper landward- and seaward-facing slopes of the bars when a large volume of sand was moving parallel to the bar axes or sand was being reworked at angles to the axes (most of lithofacies 5). Between the times of more active sediment supply and deposition, lithofacies 5 environments hosted abundant Pleurothyrella, spiriferids, and other organisms that thoroughly reworked the sediment, destroying the primary structures (lithofacies 2 and 8). Couplets of fine- to medium-grained sandstone containing ripples (lower flow regime) and planar laminations (upper flow regime) may indicate growing or decaying storm waves on the seaward sides of bar tops during deposition of lithofacies 4 (Greenwood and Mittler, 1985). Seaward of the area of most active clastic deposition, phosphatic debris (lithofacies 6) and biogenic carbonates (lithofacies 7) were deposited.

The arkosic arenite containing pebbles and climbing backflow ripples (lithofacies 9) on the west spur at Schulthess Buttress (near long $115^{\circ} \mathrm{W}$.) may represent the only fluvial deposit in the Horlick Formation. This outcrop, not represented in figure $22 \mathrm{~A}$, records the position of a river that flowed southward, carrying granitic debris to the coastline in Early Devonian time. Considering the westward longshore drift, we conclude that another river to the east must have supplied sediment to the Discovery Ridge area.

Quantitatively estimating the magnitude of tides, waves, storms, and river discharge is difficult, but some reasonable limits (based on comparison with data in Davis and Hayes, 1984) are tidal range, 1-3 m; waves, moderate height and period; several large storms every year; a major cyclonic storm every few years; river dis- 
charge, moderate in general and low in some years. The block diagram in figure $22 \mathrm{~A}$, constructed from the observed and inferred distribution of lithofacies in the Horlick Formation, shows deposits resulting from many of these environmental conditions. The hypothetical configuration was dynamic. As the environments shifted laterally in response to even subtle changes in the rate of sediment supply, downwarping or eustatic sea-level rise, and short-term water movements, the complex vertical sequence of the Horlick Formation was deposited.

\section{TECTONISM AND PALEOGEOGRAPHY}

The bulk of Horlick Formation sediment was derived from granitic rocks like those it overlies. Metamorphosed mafic xenoliths in the granitic basement are relicts of country rock that preceded the intrusions. Rocks similar to the xenoliths are in the Hart and Stewart Hills, now located $200 \mathrm{~km}$ to the northeast, and are typical sources of detrital minerals like those that gave rise to most of the diagenetic chlorite in the Horlick. Judging from current directions, we estimate that the source terrane for the Horlick lay to the north, in what is now Marie Byrd Land (fig. 1). During the Early Devonian, granitic and mafic rocks to the north were topographically higher than the Horlick Formation's sea level; they have since been downfaulted (Long, 1965; Jankowski and others, 1983) or rotated away with the motion of West Antarctica (Craddock, 1983).

No deposits are present in the Ohio Range that represent the time between intrusion of the Ordovician granite and deposition of the Horlick Formation, a span of 100 m.y. The only clues to the nature of the tectonism in the Ohio Range at that time are the actual accumulation of the Horlick, which required a gentle downwarping to the south to admit the Lower Devonian seaway, and small, steep faults associated with some of the sedimentary channels, which, because of the flatness of the Horlick, may indicate a tensional regime.

The remarkably close alignment of the escarpment shown in figure $22 B$ with the thin, shallow-water deposits of the Horlick Formation may reflect a common cause such as association with an early Paleozoic or Precambrian fault. Intrusion of the Ordovician granitic basement along such a plane of weakness is also likely.

\section{CONCLUSIONS}

The alternating fossiliferous sands and muds that became the Horlick Formation were deposited on a shallow marine shelf having a low to moderate tidal range and wave regime. Sediment was derived by rivers from an emergent granitic and metamorphic terrane to the north. Biogenic carbonate beds accumulated on the shallow shelf beyond most active clastic deposition. Longshore drift was mainly to the west.

\section{REFERENCES CITED}

Boucot, A.J., 1975, Evolution and extinction rate controls: New York, Elsevier, 427 p.

Boucot, A.J., Caster, K.E., Ives, David, and Talent, J.A., 1963, Relationships of a new Lower Devonian terebratuloid (Brachiopoda) from Antarctica: Bulletins of American Paleontology, v. 46 , no. 207, p. 81-151.

Boucot, A.J., Johnson, J.G., and Talent, J.A., 1969, Early Devonian brachiopod zoogeography: Geological Society of America Special Paper 119, 113 p.

Bradshaw, M.A., and McCartan, Lucy, 1983, The depositional environment of the Lower Devonian Horlick Formation, Ohio Range, in Oliver, R.L., James, P.R., and Jago, J.B., eds., Antarctic earth science[-International Symposium on Antarctic Earth Sciences, 4th, Adelaide, Australia, 1982, Proceedings]: Cambridge, England, Cambridge University Press, p. 238-241.

Coleman, J.M., and Gagliano, S.M., 1965, Sedimentary structures-Mississippi River deltaic plain, in Primary sedimentary structures and their hydrodynamic interpretation-A symposium: Society of Economic Paleontologists and Mineralogists Special Publication 12, p. 133-148.

Craddock, Campbell, 1983, The East Antarctica-West Antarctica boundary between the ice shelves-A review, in Oliver, R.L., James, P.R., and Jago, J.B., eds., Antarctic earth science[-International Symposium on Antarctic Earth Sciences, 4th, Adelaide, Australia, 1982, Proceedings]: Cambridge, England, Cambridge University Press, p. 94-97.

Curray, J.R., 1964, Transgressions and regressions, in Miller, R.L., ed., Papers in marine geology-Shepard Commemorative Volume: New York, Macmillan, p. 175-203.

Davis, R.A., Jr., and Hayes, M.O., 1984, What is a wavedominated coast?, in Greenwood, Brian, and Davis, R.A., Jr., eds., Hydrodynamics and sedimentation in wave-dominated coastal environments: Marine Geology, v. 60 , p. $313-329$.

Dörjes, Jürgen, Gadow, Sibylle, Reineck, H.-E., and Singh, I.B., 1970, Sedimentologie und Makrobenthos der Nordergründe und der Assenjade (Nordsee): Senckenbergiana Maritima, v. 2, p. 31-59. (English abstract and figure and table captions.)

Dott, R.H., Jr., 1964, Wacke, graywacke and matrix-What approach to immature sandstone classification?: Journal of Sedimentary Petrology, v. 34, no. 3, p. 625-632.

Doumani, G.A., and others, 1965, Lower Devonian fauna of the Horlick Formation, Ohio Range, Antarctica, in Hadley, J.B., ed., Geology and paleontology of the Antarctic: American Geophysical Union, Antarctic Research Series, v. 6 (National Research Council Publication 1299), p. 241-281.

Edwards, D., 1973, Devonian floras, in Hallam, A., ed., Atlas of palaeobiogeography: New York, Elsevier, p. 105-116.

Frakes, L.A., Matthews, J.L., Neder, I.R., and Crowell, J.C., 1966, Movement directions in late Paleozoic glacial rocks of the Horlick and Pensacola Mountains, Antarctica: Science, v. 153 , no. 3737 , p. $746-748$. 
Greenwood, Brian, and Davis, R.A., Jr., eds., 1984, Hydrodynamics and sedimentation in wave-dominated coastal environments: Marine Geology, v. 60, 474 p.

Greenwood, Brian, and Mittler, P.R., 1985, Vertical sequence and lateral transitions in the facies of a barred nearshore environment: Journal of Sedimentary Petrology, v. 55, no. 3 , p. $366-375$.

Hawkins, J.W., Jr., and Whetten, J.T., 1969, Graywacke matrix minerals-Hydrothermal reactions with Columbia River sediments: Science, v. 166, no. 3907, p. 868-870.

Hower, John, Eslinger, E.V., Hower, M.E., and Perry, E.A., 1976, Mechanism of burial metamorphism of argillaceous sediment. 1, Mineralogical and chemical evidence: Geological Society of America Bulletin, v. 87, no. 5, p. 725-737.

Hunter, R.E., Clifton, H.E., and Phillips, R.L., 1979, Depositional processes, sedimentary structures, and predicted vertical sequences in barred nearshore systems, southern Oregon coast: Journal of Sedimentary Petrology, v. 49, no. 3 , p. $711-726$.

Jankowski, E.J., Drewry, D.J., and Behrendt, J.C., 1983, Magnetic studies of upper crustal structure in West Antarctica and the boundary with East Antarctica, in Oliver, R.L., James, P.R., and Jago, J.B., eds., Antarctic earth science[-International Symposium on Antarctic Earth Sciences, 4th, Adelaide, Australia, 1982, Proceedings]: Cambridge, England, Cambridge University Press, p. 197-203.

Kraft, J.C., 1971, Sedimentary facies patterns and geologic history of a Holocene marine transgression: Geological Society of America Bulletin, v. 82, no. 8, p. 2131-2158.

Long, W.E., 1965, Stratigraphy of the Ohio Range, Antarctica, in Hadley, J.B., ed., Geology and paleontology of the Antarctic: American Geophysical Union, Antarctic
Research Series, v, 6 (National Research Council Publication 1299), p. 71-116.

McCartan, Lucy, Bradshaw, M.A., and Kellogg, K.S., 1986, Reconnaissance geologic map of the Ohio Range, Transantarctic Mountains, Antarctica: U.S. Geological Survey, U.S. Antarctic Research Program, Antarctic Geologic Map A-13, scale 1:50,000.

McCartan, Lucy, Lemon, E.M., Jr., and Weems, R.E., 1984, Geologic map of the area between Charleston and Orangeburg, South Carolina: U.S. Geological Survey Miscellaneous Investigations Series Map I-1472, scale 1:250,000.

Pettijohn, F.J., Potter, P.E., and Siever, Raymond, 1973, Sand and sandstone (study ed.): New York, Springer-Verlag, $618 \mathrm{p}$.

Reineck, H.-E., and Singh, I.B., 1975, Depositional sedimentary environments, with reference to terrigenous clastics (corrected reprint of 1 st ed.): New York, SpringerVerlag, $439 \mathrm{p}$.

Stephenson, L.W., 1929, Unconformities in Upper Cretaceous Series of Texas: American Association of Petroleum Geologists Bulletin, v. 13, p. 1323-1334.

Treves, S.B., 1965, Igneous and metamorphic rocks of the Ohio Range, Horlick Mountains, Antarctica, in Hadley, J.B., ed., Geology and paleontology of the Antarctic: American Geophysical Union, Antarctic Research Series, v. 6 (National Research Council Publication 1299), p. 117-126.

U.S. Geological Survey, 1963, [Topographic map of the] Ohio Range, Antarctica: Washington, D.C., scale 1:250,000.

Wunderlich, Friedrich, 1970, Genesis and environment of the "Nellenköpfchenschichten" (lower Emsian, Rheinian Devon) at locus typicus in comparison with modern coastal environment of the German Bay: Journal of Sedimentary Petrology, v. 40, p. 102-130. 


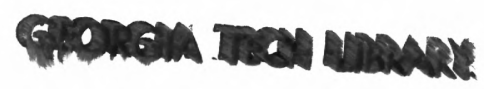



